\title{
The Great Mineral Fields of Africa
}

\section{Introduction}

\author{
Susan Frost-Killian ${ }^{1}$, Sharad Master ${ }^{2}$, Richard P. Viljoen ${ }^{3}$ and Michael G.C. Wilson ${ }^{4}$ \\ ${ }^{1}$ The MSA Group, 20B Rothesay Avenue, Craighall Park, 2196, South Africa. E-mail: susanf@msagroupservices.com \\ ${ }^{2}$ Economic Geology Research Institute, School of Geosciences, University of the Witwatersrand, \\ P. Bag 3, WITS 2050, Johannesburg, South Africa. E-mail: Sharad.Master@wits.ac.za. \\ ${ }^{3}$ VM Investment Company, Illovo Edge Office Park, cor. Harries and Fricker Road, Illovo, \\ Johannesburg. E-mail: Richard.viljoen@vmic.co.za \\ ${ }^{4}$ Economic Geology Consultant and Technical Editor, 26 Skuinsbank Street, Herold's Bay, \\ George, South Africa. E-mail: mwilson.geo@gmail.com
}

\section{DOI: 10.18814/epiiugs/2016/v39i2/95770}

The mineral wealth and potential of the African continent has been recognised for centuries and various minerals have been exploited from different parts of the continent for many millennia. Gold, copper and iron mining and metallurgy are believed to have first developed in Egypt, in the third and second millennia BCE and somewhat later in other parts of the continent. Ancient gold workings abound in many parts of Africa, with some of these having become successful gold mines during the period of colonisation. Over the past half century, many of these mines, as well as some previously unknown deposits, have become major gold producers following various prospecting endeavours using more modern exploration techniques. Besides gold, copper and iron, a number of other minerals were exploited in pre-historic times from various parts of the continent. Notable amongst these were lead, zinc and tin. New deposits and occurrences, as well as extensions to existing deposits are still being discovered to this day as exploration continues unabated. The continent is one of the world's last frontiers of untapped minerals and many exploration and mining opportunities still exist.

The type and distribution of various mineral provinces, deposits and occurrences, is directly related to the geological and tectonic framework of the continent. While most of the major gold and all of the primary diamond (in kimberlite), platinum, chrome and vanadium deposits, are associated with Archaean age cratonic nuclei (with the exception of the gold deposits hosted in the Birimian of West Africa), many base metal deposits are hosted in lithologies of the younger Proterozoic metamorphic mobile belts. Extensive deposits of coal, oil, gas and heavy mineral sands, are hosted in large Phanerozoic basins and in Holocene sediments.

Reviews of some of the great mineral fields and examples of some deposits within them are presented in this volume, however in-depth accounts of the geology and the huge number of mineral deposits of the continent is beyond the scope of this publication. In order to place the deposits in their regional geological context, a brief review of the geological framework of Africa and its mineral fields is presented, with the simplified geological framework and the position of some major deposits and mineral fields being shown on the accompanying maps (Figures 1a, 1b and 2).

\section{Geological Framework of Africa}

Geological mapping of Africa was initiated in the $19^{\text {th }}$ Century. Large areas of the continent were mapped in the $20^{\text {th }}$ Century during the colonial era, with the establishment of national geological surveys across much of the continent. The task of mapping is however far from over, with large areas of Africa only mapped on a reconnaissance scale. The Commission for the Geological Map of the World (CGMW), an affiliate of the International Union of Geological Sciences (IUGS), has been responsible for coordinating several continent-scale maps including the 1:5 million scale International Geological Map of Africa ( $3^{\text {rd }}$ edition 1985-1990), the International Metallogenic Map of Africa (2002) and the Tectonic Map of Africa (2010). Further regional and continental wide maps, at a variety of scales, have been produced by other organisations.

The simplified maps produced in this chapter (Figures 1a,1b and 2) have been adapted to facilitate the description of some of the major mineral deposits and metallogenic provinces in Africa and have been compiled from various sources (see reference list at the end of the paper). The major geological entities of the African continent are briefly described below.

\section{Archaean Nuclei, Cratons, Shields and Platforms}

Continental crust is generally divided into old stable regions called cratons, which are characterised by thick lithosphere, and generally younger tectonised regions referred to as mobile belts, characterised by intense regional deformation and metamorphism, as well as a thinner lithosphere. Where the crystalline igneous and metamorphic rocks of the cratons are exposed, they are called shields or shield areas. In most places the cratons are covered by younger sedimentary basins, referred to as platform sediments. The cratons have grown in size throughout geological history, starting with Archaean nuclei consisting of greenstone belts, and tonalite-trondhjemite-granodioritic plutons and their deformed gneissic equivalents. Larger stable cratons formed through the accretion of belts of Proterozoic to Palaeozoic age rocks onto the Archaean cratonic nuclei, followed by stabilisation. 


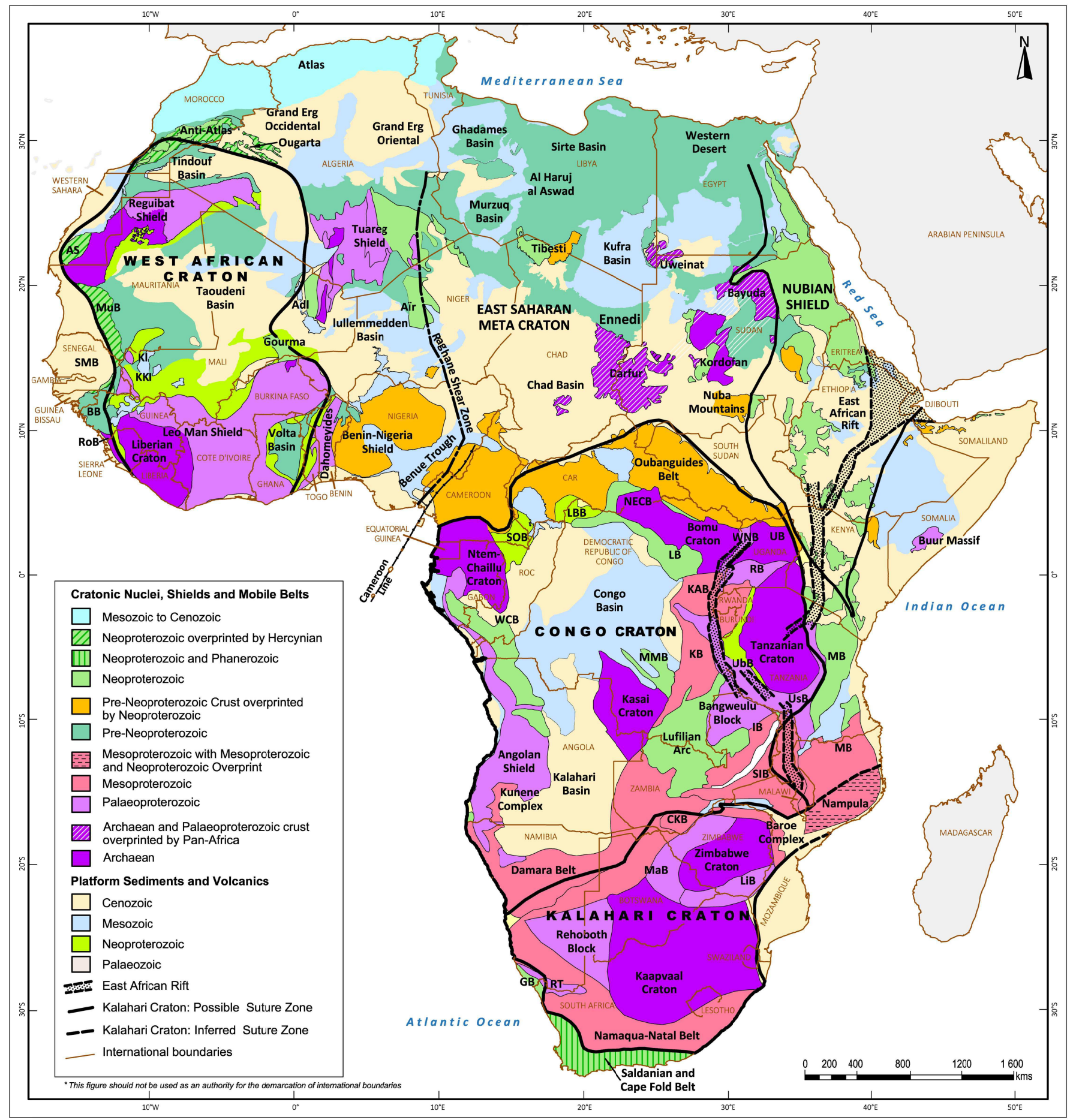

Figure 1a. Simplified Geological Framework of Africa.

Cratons, Shields, Mobile Belts, Massifs and Basins: AdI - Adrar des Iforas Massif; AS - Adrar Souttouf Massif; CKB - Choma-Kalomo Block; EAR - East African Rift; GB - Gariep Belt; IB - Irumide Belt; KAB - Karagwe-Ankolian Belt; KB - Kibara Belt; KI - Kayes Inlier; KKI - Kédougou-Kéniéba Inlier; LB - Lindian Belt; LBB - Liki-Bembe Basin; LiB - Limpopo Belt; MB - Mozambique Belt; MaB Magondi Belt; MMB - Mbuji-Mayi Basin; MuB - Mauritanide Belt; NECB - North East Congo Block; RB - Ruwenzori Belt; RoB Rokelide Belt; RT - Richtersveld Terrane; SIB - Southern Irumide Belt; SOB - Sembe-Ouesso Basin; UB - Uganda Block; UbB - Ubendian Belt; UsB - Usagaran Belt; WCB - West Congo Block; WNB - West Nile Belt.

Countries: CAR - Central African Republic; ROC - Republic of Congo (Brazzaville). The boundaries of the three great African cratons are defined by mapped or inferred sutures which separate them from adjoining regions. In places these boundaries occur within Pan African mobile belts. 


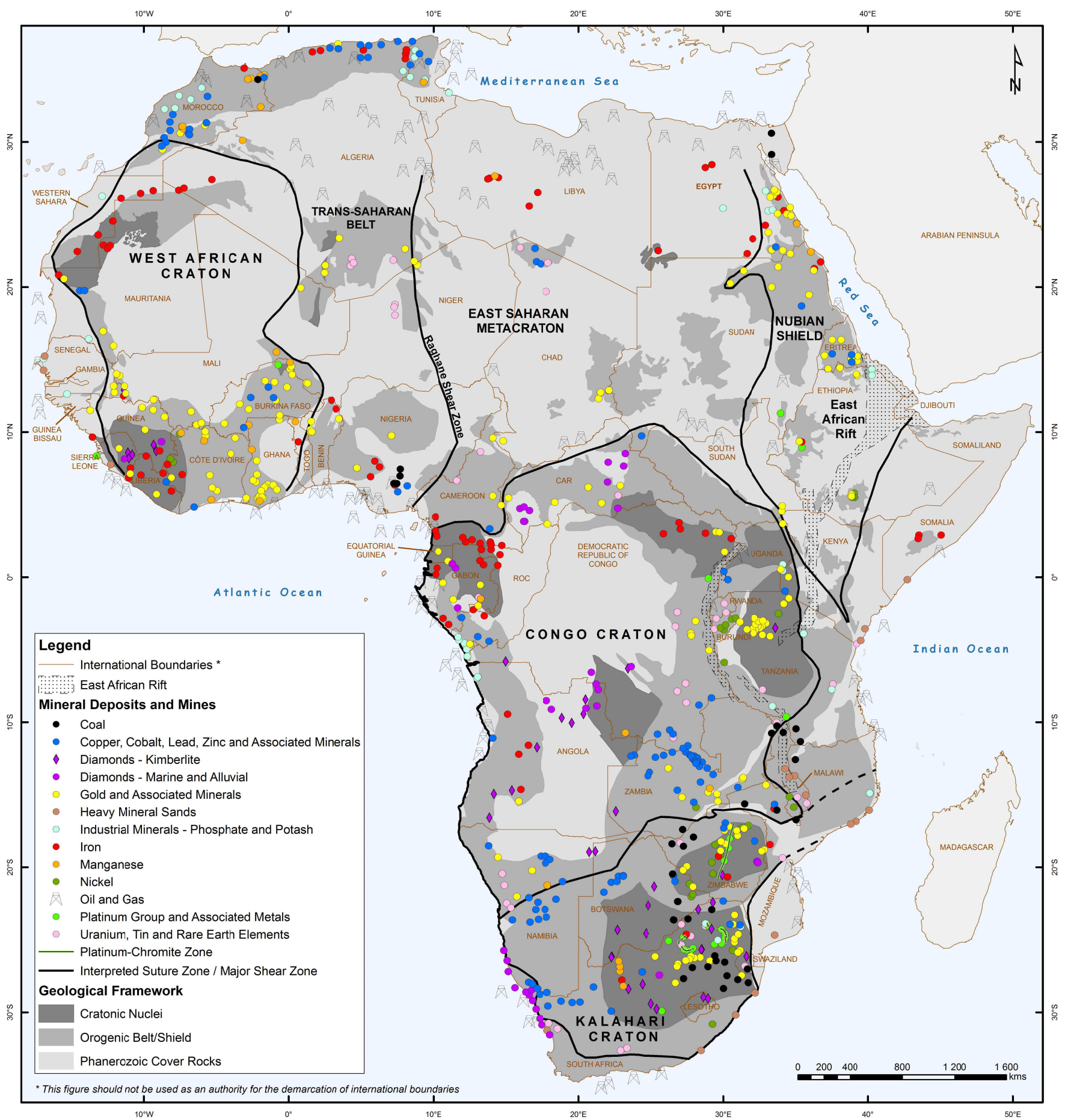

Figure 1b. The Major Mineral Deposits of Africa. Location of significant mines, mineral deposits and mineral exploration projects. In parts, smaller deposits are shown in order to emphasise the Great Mineral Fields or important areas of mineralisation. Only selected commodities have been included. Major geological components of the three great African cratons and their surroundings are depicted in the background.

Collisions between, and suturing of, these larger cratons resulted in even larger composite cratons.

The continental African plate as we see it today consists of three major cratons, namely the West African, Greater Congo and Kalahari Cratons, which grew through Palaeoproterozoic and Mesoproterozoic orogenesis, and which had stabilised by the late Neoproterozoic. These three large Neoproterozoic cratons collided and accreted during the $550 \pm 100$ Ma "Pan-African" and "Brasiliano" tectonothermal events which resulted in the amalgamation of the supercontinent of Gondwanaland. The present-day continental African plate is not entirely rigid and stable as there has been relative movement between its component cratons and the surrounding mobile belts, which have been re-activated along shear zones and other structures during Phanerozoic plate movements.

Africa acquired its current shape only after the Jurassic to Cretaceous break-up of the Gondwanaland supercontinent and the 
formation of the Atlantic and Indian Oceans, and the Miocene opening of the Red Sea which resulted in the rifting away of the Arabian plate. The African plate is currently undergoing rifting along the East African Rift System, and its future shape will change should the Horn of Africa rift away completely.

During the Neoproterozoic another large craton, called the "West Nile" or "East Saharan" Craton, existed in what is now northeast Africa. This craton behaved in a rigid manner during Pan-African collisions with the West African Craton to form the Trans-Saharan Mobile Belt, and with the Greater Congo Craton to form the Oubanguide Belt. However, at different times during these collisional events, the thick lithospheric root under this "East Saharan Craton" became delaminated and was replaced by fertile asthenospheric mantle (Karmakar and Schenk, 2015). The region then lost its rigid "cratonic" character, and was intruded by large volumes of late Pan-African granites, Mesozoic to Cenozoic ring complexes, as well as large igneous provinces (LIPs) such as in the Nigerian ring complexes, the Tibesti uplift of northwestern Chad and southwestern Libya, the Cameroon volcanic line, the El Haruj el Aswad and other LIPs of central Libya, the Jebel Marra LIP in western Sudan and ring complexes of Jebel Uweinat and Jebel Arkenu, in southeastern Libya (Abdelsalam et al., 2002). The East Saharan region is now referred to as the "East Saharan Metacraton" (Abdelsalam et al., 2002), or the East Saharan Ghost Craton (Karmakar and Schenk, 2015).

The oldest rocks of the African continent are the Archaean nuclei of the cratons (Figure 1a). These nuclei $(>2.5 \mathrm{Ga}$ ) are comprised of a variety of granitoids with associated greenstone belts. They represent the cores around which the African cratons were accreted and are of great significance from a metallogenic point of view. Several generally well defined Archaean nuclei are present on the African continent, including the Kaapvaal and Zimbabwe nuclei of the Kalahari Craton; the Tanzanian, Bomu (northeast Democratic Republic of Congo (DRC)), North Uganda, Kasai, and Ntem nuclei of the Greater Congo Craton, and the Kénéma-Man and Reguibat nuclei of the West African Craton.

The Archaean nuclei host a variety of world class mineral deposits (of various ages), of which gold, platinum, diamonds, iron ore and manganese are some of the most important (Figures 1b and 2).

\section{Metamorphic Mobile Belts}

The Archaean cratonic nuclei are surrounded by younger metamorphic mobile or orogenic belts. These mobile belts vary in age, from the Paleoproterozoic to Neoproterozoic. They represent the metamorphosed roots of older orogenic fold belts that have been subjected to reactivation at various stages through geological time. They vary considerably in size, geology, degree and nature of tectonism and metamorphism and in their contained mineral deposits. Mobile belts may represent collision zones between cratonic blocks, accompanied by major tectonic uplift, metamorphism and erosion. In many instances, the cratonic rocks have been subjected to reworking and metamorphism within the mobile belts. In other instances, the mobile belts comprise accreted terrains and collisional zones, or they may represent aulacogens, or failed rifts. The older mobile belts were those along which Archaean nuclei were originally sutured (or joined together along fault zones) and became stabilised with time through the acquisition of thicker lithospheric roots, becoming "cratonised," and in this way the cratons have grown. All of the Proterozoic mobile belts older than the "Pan-African" mobile belts were already part of the enlarged cratons during the formation of Gondwanaland. The three large African cratons that were involved in the Pan-African orogenic events, were themselves consolidated during earlier Palaeoproterozoic and Mesoproterozoic orogenies.

In the Kalahari Craton, the Kaapvaal and Zimbabwe cratonic nuclei were amalgamated along the Limpopo-Magondi orogenic belts during the Palaeoproterozoic. Mesoproterozoic belts, including the Natal-Namaqua, Rehoboth, Ngamiland and Choma-Kalomo Belts, surround this Archaean-Palaeoproterozoic core. In the Greater Congo Craton, Palaeoproterozoic belts such as the West Nile, Ruwenzori, Ubendian and Usagaran Belts, the West Central African Belt of Gabon, and the southern Angolan shield, together with the Mesoproterozoic Kibaran, Karagwe-Ankole, Irumide and southern Irumide Belts, led to the suturing of the older Archaean nuclei of the Kasai, Tanzania, North Uganda, Bomu and Ntem shields. In the West African Craton, the Archaean nuclei of Kénéma-Man and Reguibat, were accreted to the Palaeoproterozoic island arc and andean arc terrains of the Birimian volcano-sedimentary belts.

Sedimentation and basin development has taken place within some mobile belts. The sediments, which have undergone varying degrees of metamorphism, are frequently host to base metal deposits. They include the large Neoproterozoic copper-cobalt deposits of Zambia and the DRC, as well as the copper, lead and zinc deposits of the Bushmanland sequence of the Mesoproterozoic Namaqua Mobile Belt of South Africa and the Neoproterozoic Damara, Gariep and Kaoko Belts of Namibia. Granitoid intrusions into the mobile belts have given rise to important tin, tungsten, tantalum and rare earth element deposits such as those of the Damara Belt of Namibia, the Namaqua Belt of South Africa and Namibia, the Kibaran Belt of the eastern DRC, the Karagwe-Ankole Belt of Burundi, Rwanda and southwest Uganda, and the Nubian shield of Ethiopia, Somalia, Eritrea, Sudan and Egypt (Figure 1a).

\section{Sedimentary Basins}

Sedimentary basins, which also vary considerably in age, from Archaean to Holocene, occur throughout the continent and overlie parts of the cratons and mobile belts. They are hosts to important mineral deposits in various parts of Africa.

A remarkable succession of these basins, varying in age from 3.0 billion years to 1.8 billion years, have been preserved on the Kaapvaal Craton of South Africa and provide many clues regarding the development of the atmosphere and biosphere. They are of particular importance in that they contain some of the continent's great mineral deposits including gold, iron and manganese (Figure 2). The size of the basins varies with age, with the oldest generally being the smallest and the youngest the largest. Some of the younger, larger basins extend onto the adjoining metamorphic mobile belts. In such instances they have been affected to varying degrees by metamorphism or tectonism related to varying phases of reactivation of the mobile belt(s).

In South Africa, the Main Karoo Basin is the largest Phanerozoic sedimentary basin, ranging in age from late Carboniferous to early Jurassic. Similar aged rift basins are found throughout South, Central and East Africa, and extend into most other parts of Gondwanaland. These basins host the Glossopteris flora which has given rise to many of the most important coalfields of Africa. In North Africa, large Palaeozoic to Cenozoic basins cover the Pan-African and older basement. Together with Cretaceous aged rift basins formed during 


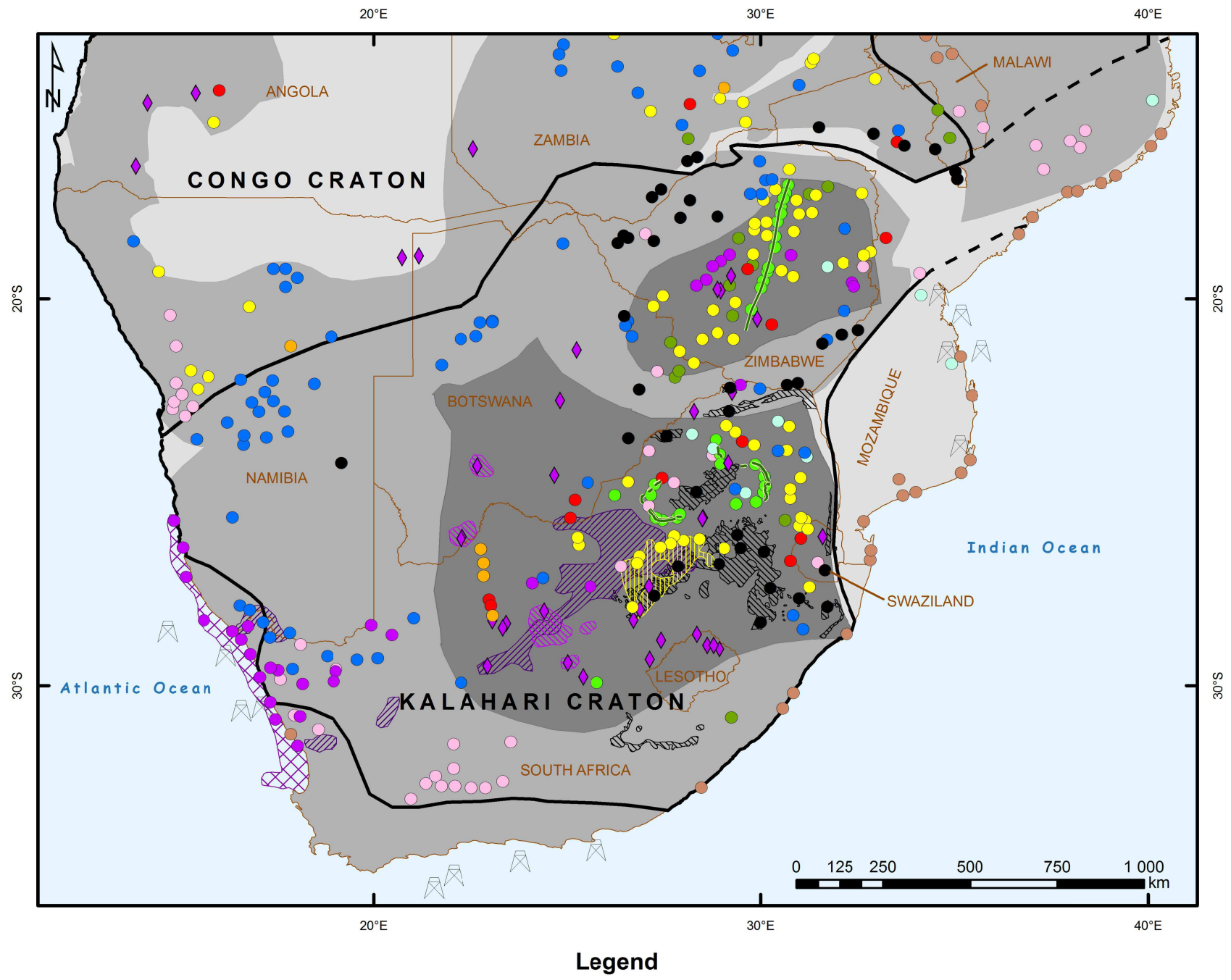

Mines and Deposits

Copper, Cobalt, Lead, Zinc

- and Associated Minerals

- Diamonds - Marine and Alluvial

$\checkmark$ Diamonds - Kimberlite

- Gold and Associated Minerals

- Heavy Mineral Sands Industrial Minerals - Phosphate and Potash

- Iron

Manganese

- Nickel

\& Oil and Gas

- Platinum Group and Associated Metals

Uranium, Tin and Rare Earth Elements

\section{Mineral Fields}

X Marine Diamonds Coal
Diamondiferous Kimberlites

Witwatersrand Basin
Geological Framework

Cratonic Nuclei

Orogenic Belt/Shield

Phanerozoic Cover

Interpreted Suture between Cratons

_ International Boundaries

VIIII Alluvial Diamonds

— Platinum-Chromite Zone

Figure 2. The Major Mineral Deposits and Mineral Fields of the Kalahari Craton, Southern Africa._Significant mines, mineral deposits and mineral exploration projects of the Kalahari craton and surrounding areas. The mineral deposits shown provide an overview of the substantial mineral legacy of the Kalahari Craton. Only major mineral commodities have been included.

the opening of the Atlantic Ocean, they are hosts to the major accumulations of oil and gas in Africa (Figure 1b). Recent coastal sediments host significant alluvial diamond fields and important heavy mineral sand deposits (Figures $1 \mathrm{~b}$ and 2).

\section{Igneous Intrusions}

A feature of the continent is the large variety and age span
(Archaean to Holocene) of predominantly mafic, magmatic intrusions into cratons, mobile belts and sedimentary basins. These intrusions may take the form of pipes, volcanic complexes, dykes, sills, laccoliths, lopoliths, significant layered intrusions (Bushveld, Great Dyke) and large igneous provinces. They vary in composition from ultramafic to mafic and felsic, with carbonatite and kimberlite intrusions also present. These intrusions host some of the most important mineral deposits of the continent. Rare earth elements, phosphate and copper 
are associated with alkaline intrusives, while all the important primary diamond deposits occur on the cratons and are related to kimberlite pipes and dykes. A variety of intrusions of various ages and types are also an integral part of the mobile belts and, in places, host important mineral deposits. Ring complexes of alkaline granite and syenite are commonly found in Africa, especially in those regions that experienced Pan-African orogenesis. They host deposits of tin, tantalum, niobium, tungsten, rare earth elements, beryllium and fluorite.

\section{Mineral Deposits and Mineral Fields}

The mineral deposits and mineral fields of the continent are briefly discussed according to their commodities, geological setting and tectonic framework, as outlined above and shown in Figures $1 \mathrm{a}, 1 \mathrm{~b}$ and 2 .

\section{Gold}

The mining of gold has always been associated with Africa, with gold artefacts and jewellery having been found in localities as far afield as Egypt, Nubia (Sudan), West Africa and South Africa (Mapungubwe on the banks of the Limpopo River). Ancient gold workings abound in many parts of the continent including South Africa, Zimbabwe, West, North and Northeast Africa amongst others. In Ghana, ancient workings were a prelude to the founding of the great Ashanti Empire and the establishment of the famous Gold Coast, the forerunner of modern day Ghana.

Most of the large goldfields of the continent occur in the ancient cratons, commonly in greenstone belts and more rarely, associated with granitoids. Gold mineralisation, which can occur in a variety of host rocks, is frequently associated with major structures, or important terrain boundaries, or zones of competency contrast. The deposits are generally classified as orogenic gold deposits. In West Africa most of the gold deposits, which are not unlike those of the Archaean greenstone belts, are associated with major structures in the younger Palaeoproterozoic volcano-sedimentary belts of the West African shield.

The Nubian shield, the Damara Belt gold province of central Nambia and the Hoggar region of the Trans-Saharan Mobile Belt, are important younger Neoproterozoic gold provinces which are currently attracting attention from exploration and mining companies.

\section{Goldfields of the Archaean Cratonic Nuclei}

The Archaean greenstone belts of the Kaapvaal Craton of South Africa are perhaps the best studied and host small- to medium-sized gold mines. Most of the gold has been won from the Barberton Greenstone belt, which is well known for the clues it has yielded regarding early life and earth processes. It is also the type area for komatiites, mafic and ultramafic volcanics and intrusives, which are associated with a number of important types of mineralisation in Africa and elsewhere. Several distinct styles of gold mineralisation have been identified in the Barberton Greenstone belt, including lode gold deposits associated with a variety of structural settings. More competent and reactive rock types and lithologies, with competency contrast, are particularly favourable hosts and carbonated shear zones within ultramafic rocks are often associated with antimony mineralisation and constitute a particular style of mineralisation in the Barberton and Murchison Greenstone belts. The Consolidated
Murchison mine was the largest producer of antimony in the world for several decades. Sulphidised banded iron formations also host gold mineralisation, as do iron-rich shales and greywackes which are also associated with arsenical mineralisation.

One of the earliest sedimentary basins deposited entirely within the confines of the Kaapvaal Craton is the Witwatersrand Basin which formed some 2.8 billion years ago. It is the world's largest known gold deposit and was the world's largest gold producer for 100 years, having produced a third of all the gold ever mined (see Tucker et al., this volume). The closest analogy to the Witwatersrand deposits outside of South Africa, are the gold-bearing conglomerates of the Tarkwa Belt in Ghana, hosted by sediments of the West African Shield (see Smith et al., this volume).

Over 4,000 ancient gold workings are known from the Zimbabwe Craton and numerous small- to medium-scale gold mines have produced, and in some cases are still producing, gold. Nearly all of these mines were established on ancient workings. Models of gold mineralisation are similar to those for the Kaapvaal Craton, with a number of large mines such as the Gaika being associated with antimony mineralisation in carbonated ultramafic rocks. All the large gold mines are associated with major structures, with mineralisation occurring in banded ironstones and other more competent rock types including mafic and felsic volcanics. The older multi-million ounce gold deposits in Zimbabwe include the Globe and Phoenix, Cam and Motor and Sherwood Star Mines, while a new generation of restarted old mines and new mines are operating at present, an example being the Blanket Mine (Foster et al., 1986).

The Congo Kasai Craton covers a large area in central Africa but it is largely covered by younger sediments of the Congo Basin. A number of small gold deposits occur in an Archaean granite greenstone window in the southwestern DRC and northeast Angola and in the northwestern portion of the craton in the Republic of Congo and Cameroon (Figure 1a). Virtually all the deposits have a resource of less than one million ounces of contained gold.

Gold has been extracted from the northeastern portion of the Congo Craton since colonial times, with mines such as Kilomoto having produced significant amounts of the metal. Recent work has established a mineral resource of over 20 million ounces of gold at the old Kibali Mine, where mineralisation occurs in a number of high grade shoots along a major shear zone.

Following a spate of exploration programmes, commencing in the 1980s, greenstone belts of the Tanzanian Craton, which had previously been known to host a few small gold mines based on ancient workings and developed during colonial times, now contains several world class gold mines such as the Geita and Bulyanhulu. A number of mineralisation models similar to those developed and postulated for gold deposits in the other Archaean cratons and useful for gold exploration programmes, have been established (Henckel et al., this volume). Gold mineralisation is associated with several greenstone belts in the Kénéma-Man Craton of Liberia and Sierra Leone. The mineralisation occurs in structurally controlled quartz-pyritearsenopyrite lodes and is frequently hosted in banded iron formation and amphibolites. The 1.7 million ounces of gold at the New Liberty gold mine in western Liberia are hosted in quartz lodes within an ultramafic body. A major shear zone in the central portion of eastern Liberia is considered to be the boundary between the Archaean and Palaeoproterozoic and this has become an important exploration target.

The gold potential of the Reguibat Archaean nucleus in northwestern Africa is considered to be limited, since it consists mainly 
of granitoid gneisses and amphibolite-grade supracrustals. An exception is the 9.6 million ounce Tasiast deposit, hosted by banded iron formations in a narrow greenstone belt on the very southern edge of the Reguibat Shield (see Robertson and Peters, this volume).

\section{Goldfields of the Proterozoic Shields}

\section{Birimian of the West African Craton}

The West African Craton comprises the Kénéma-Man and Reguibat Archaean cratonic nuclei, separated by and flanked to the east by a vast area of Palaeoproterozoic rocks of the Birimian Supergroup, consisting of faulted and folded volcano-sedimentary basins and volcanic belts, with a variety of intrusive granitoids. In places, notably in Ghana, the Birimian volcano-sedimentary rocks are overlain by a younger succession of dominantly arenaceous sediments with associated conglomerate layers, known as the Tarkwaian Group. Important gold deposits are hosted in the conglomerate bands as well as being structurally controlled.

Some seventeen gold mines, most of which have come into production in the past 20 years, occur in the Palaeoproterozoic Birimian terrain of West Africa that has become one of the world's premier gold provinces. Various gold deposit types and models have been recognised including orogenic intrusion-related, skarn-hosted, porphyry-hosted, and iron oxide-copper gold (IOCG) deposits. Although major controls of mineralisation are broadly similar, gold distribution patterns are highly variable at a local scale (see Robertson and Peters, this volume and Smith et al., this volume).

\section{Ubendian Belt, Tanzania- Lupa and Mpanda Goldfields}

The Palaeoproterozoic Ubendian Mobile Belt of southwestern Tanzania, with a complex history of multiple collision, accretion and strike-slip reactivation events, has two goldfields, the Lupa and Mpanda, which were formed during two different tectonic events. The Lupa gold mineralisation is in the form of auriferous quartzsulphide veins, emplaced between $1.95 \mathrm{Ga}$ and $1.87 \mathrm{Ga}$, during transpressional orogenesis (Lawley et al., 2013a, b). The Mpanda goldfield consists of quartz-galena veins emplaced during the Mesoproterozoic Kibaran orogeny (Nanyaro, 1989).

\section{Limpopo Belt, Zimbabwe and South Africa}

The Limpopo Mobile Belt, consisting of upper amphibolite to granulite facies gneisses, is found between the Archaean Zimbabwe and Kaapvaal nuclei of the Kalahari Craton. It has a polyphase structural and metamorphic history, which records events at approximately $2.6 \mathrm{Ga}$, and at approximately 2.0 Ga. The North Marginal Zone of the Limpopo Belt hosts the high grade Renco gold mine in Zimbabwe (with production of $1.19 \mathrm{Moz}$ of gold from 7.2 Mt ore at an average grade of $6 \mathrm{~g} / \mathrm{t} \mathrm{Au}$ ), whilst the South Marginal Zone of the Limpopo Belt in South Africa, hosts the small Doornhoek gold mine. These deposits, which were formed during prograde metamorphic events, demonstrate unequivocally, the possibility of forming economic gold deposits under granulite facies conditions. They open up possibilities for gold exploration in vast areas of Africa within high-grade gneisses, which have traditionally been neglected by exploration companies in the past.

\section{Goldfields of the Pan-African Mobile Belts}

\section{The Nubian Shield}

The Nubian Shield and coeval rocks in the western part of the Arabian Peninsula form the composite Arabian-Nubian Shield (ANS), which flanks the Red Sea and comprises predominantly juvenile Neoproterozoic rocks. In northeast Africa, the Nubian Shield stretches from the Sinai Peninsula and Egypt in the north, through Eritrea and Ethiopia to Sudan, South Sudan, Somaliland and Kenya in the south (Figures 1a and 1b).

It evolved as an accretionary orogen over a period of approximately 300 million years, from about 850 to 550 Ma. Rock types present include metavolcanic and metasedimentary rocks, gabbros, gneisses, granitoids, and ophiolites, amongst others. The most important types of gold deposits include: gold associated with volcanogenic massive sulphides (VMS) and oxide gold in the weathered zones above the VMS deposits; and gold-bearing quartzvein systems, or orogenic gold (Johnson, 2016; Groves, 2015). To a lesser extent, other types of gold occurrences include alluvial gold and gold mineralisation associated with altered ultramafic rocks (listwaenite), banded-iron formation, and tin \pm tungsten \pm molybdenumbearing granites.

In 2014 there were more than 30 exploration and/or mining projects targeting gold, gold-copper, or gold and other base metals in the Nubian shield (Brooke Pattrick Publications, 2014). VMS-hosted gold projects include, amongst others, the Bisha gold-silver-copperzinc mine (circa $0.72 \mathrm{Moz}$ contained gold) in Eritrea (Gribble et al., 2013), and the Hassai Mine and VMS-hosted gold project in Sudan. Orogenic gold projects include, amongst others: the Sukari gold mine (measured and indicated mineral resource of approximately $13 \mathrm{Moz}$ contained gold (Centamin, 2015)) and the Hamash Gold Mine in Egypt; the Lega Dembi Mine, Sakaro Mine and Tulu Kapi Project in Ethiopia; the Koka (Zara) Project and the Asmara Project in Eritrea; and the Galat Sufar South Project in Sudan.

Other mineralisation associated with the Nubian Shield includes base metals, banded iron formation, tin-tungsten, tungstenmolybdenum, tin-niobium-tantalum, platinum, chrome and mica.

\section{The Damara Mobile Belt, Namibia}

The Damara Mobile Belt of Namibia is a Pan-African belt formed by the collision of the Kalahari and Greater Congo Cratons. It consists of strongly deformed platform to basinal sedimentary and volcanic sequences, which have been intruded by syn- and late-tectonic granites, and post-orogenic alkaline ring complexes. The deformed rocks, which belong to the Neoproterozoic Damara Supergroup, are host to a variety of mineral deposits, some of which were formed by fluids mobilised during regional deformation (lead, zinc, copper), while others are related to intrusive granitoids and pegmatites (e.g., uranium, tin, tungsten, and tantalum-niobium). There are two large gold deposits in the Damara Belt, the Navachab Mine, which commenced operations in 1988, and the Otjikoto Mine, which opened in 2014.

The Navachab gold deposit, the largest gold mine in Namibia, lies in the southern Central Zone of the Damara Belt and has an estimated ore reserve of 1.2 Moz of gold, at an average grade of 1.6 to $2.0 \mathrm{~g} / \mathrm{t} \mathrm{Au}$ (Steven and Badenhorst, 2002). The gold is hosted in structurally-controlled quartz veins with sulphides, and near-massive 
sulphide lenses, emplaced into an amphibolite grade metamorphosed shelf-type carbonate succession consisting of biotite schists, calcsilicate rocks, and dolomitic marbles. The ore minerals include sulphides such as pyrrhotite, chalcopyrite, sphalerite, arsenopyrite, bismuth, bismuthinite and bismuth tellurides, together with gold. Because the calc-silicate host rocks contain assemblages with garnets, clinopyroxenes, and potassic (K)-feldspar, the mineralisation was regarded as a 'skarn' deposit, possibly related to regional granitic intrusions. Recent petrological work indicates that these assemblages are the result of high-temperature, low pressure amphibolite grade metamorphism (Wulff et al., 2010).

The mineralisation at Navachab and the surrounding prospects is found in the near-vertical north-western limb of a doubly plunging anticlinal dome, the Karibib Dome. The Navachab district potentially hosts more than 5 million ounces of gold. There is no isotopic evidence for the involvement of granitic sources for the fluids, although regional granites related to late-Damaran extension at 530 - $500 \mathrm{Ma}$, may have played a role in imparting the very high geothermal gradients $\left(80^{\circ} \mathrm{C} / \mathrm{km}\right.$ ) in the mineralised region (Wulff et al., 2010).

The size and style of mineralisation at the Otjikoto gold mine appears to be similar to that at Navachab, but there are no detailed published studies as yet. There is a declared Probable Mineral Reserve of $26.3 \mathrm{Mt}$ of ore at an average grade of $1.41 \mathrm{~g} / \mathrm{t} \mathrm{Au}$, containing 1.2 Moz of gold (B2Gold, 2016).

\section{Gold in the Hoggar, Tuareg Shield (Trans- Saharan Mobile Belt)}

The Hoggar region of southern Algeria is the central part of the Tuareg Shield, which is the northernmost exposed portion of the TransSaharan Mobile Belt. This large region consists of a number of different Pan-African island arc terranes, with slivers of older Archaean and Palaeoproterozoic continental fragments juxtaposed along major north-south trending shear zones. This mobile belt was the product of collision and terrane accretion during the Neoproterozoic, when the West African and the East Saharan Cratons collided. Within the Hoggar region, the Amesmessa and Tirek gold deposits are the only two currently and past producing gold mines respectively, within this large Pan-African mobile belt. Numerous smaller deposits have been identified between these two deposits, and the region appears to have potential for more deposits of a similar type (Figures 1a and 1b).

The Amesmessa gold deposit is situated about $450 \mathrm{~km}$ southwest of Tamanrasset, in the Hoggar region of southern Algeria, close to the Mali border. It lies along a major north-south ductile shear zone, which is two to three kilometres wide and 50 kilometres long, forming a terrane boundary that separates the Archaean, In Ouzzal terrane, from a Palaeoproterozoic terrane to the east of it. The mineralisation is hosted by quartz veins containing pyrite, galena and rare sphalerite, together with gold. The veins are mainly shear hosted, and rarely occupy tension gashes. There are dozens of vein clusters found over a north-south strike length of 12 kilometres. The Amesmessa mine has a total mineral resource, in 16 veins, hosting $1.4 \mathrm{Moz}$ of gold, to a depth of $400 \mathrm{~m}$ (ENOR, 2012).

The Tirek gold-silver deposit is situated $64 \mathrm{~km}$ north of Amesmessa, and is similar in its geology. It was mined between 2001 and 2007, with 57,000 ounces of gold produced by a carbon in leach (CIL) process. It has an estimated mineral resource of $0.59 \mathrm{Mt}$ of ore at an average grade of $25 \mathrm{~g} / \mathrm{t} \mathrm{Au}$, or $0.48 \mathrm{Moz}$ contained gold (ENOR, 2012).

\section{Diamonds}

The association of diamondiferous kimberlites with "rigid cratonic nuclei of respectable antiquity" in Africa, was recognised by Kennedy (1964). This association was subsequently formalised by Clifford (1966) and became known as "Clifford's Rule", which states that diamond bearing kimberlites are to be found only on the stable cratonic nuclei, where the minimum age of the last thermal event is 2,500 Ma, or Archaean. The deep "cold roots" of the cratons have temperatures low enough and pressures high enough for diamonds to form in what is termed the diamond window. Diamond bearing Kimberlites occur in all the Archaean nuclei of Africa, with some of the largest pipes and dykes emplaced into the Kaapvaal and Zimbabwe cratons. They range in age from Archaean to Eocene (see de Wit et al., this volume).

A variety of sediments containing diamonds, all derived from the diamond-bearing kimberlites of the Archaean cratons, occur throughout Africa. Uplift and erosion of the high interior plateau of southern Africa in particular, has resulted in a more than one kilometre lowering of the old land surface formed on the cratons and adjoining areas, particularly in the valleys of the Orange and Vaal rivers of South Africa. Diamonds liberated from the kimberlites were washed down the rivers and concentrated in gravels, dating from about 18 million years ago. These now form old terraces at various elevations, flanking the rivers. Alluvial diamonds were finally concentrated by wave action along the palaeo-beaches of the southwest African coastline and were also concentrated on the offshore African continental shelf (marine diamonds). Alluvial diamonds are also associated with the river systems of the Angola, Congo and KénémaMan Cratons (see de Wit et al., this volume).

\section{Platinum Group and Associated Metals}

Africa hosts by far the world's greatest resources and reserves of the Platinum Group Elements (PGEs) (platinum, palladium, rhodium, ruthenium, osmium, and iridium) as well as chrome, and vanadium. These metals and minerals have been concentrated in layers in mafic rocks of the Bushveld Complex of South Africa (see Viljoen, this volume) and the Great Dyke of Zimbabwe. The Bushveld Complex was emplaced as a series of sills or sheets, intruded mainly into sedimentary formations of the Transvaal Supergroup in the north central portion of the Kaapvaal Craton. The first manifestation of this igneous activity commenced about $2.05 \mathrm{Ga}$, with the outpouring of huge amounts of felsic volcanics below which the mafic rocks were emplaced as sheets. Magmatic segregation within the various intrusive sheets gave rise to extensive layers containing concentrations of the PGEs, together with copper and nickel sulphides, as well as chromite, in chromitite layers within the mafic to ultramafic rocks. Vanadium-bearing titaniferous magnetite and phosphate (apatite)bearing layers, occur at the top of the sequence of layered mafic rocks.

Towards the waning phase of plume activity, sheets of granitic magma were emplaced above the uppermost mafic rocks. The younger, more evolved of these I-type granites contain significant concentrations of tin, fluorite, and rare earth elements. Significant andalusite deposits have formed and are exploited, within the metamorphic aureole of the Bushveld Complex. Phalaborwa, a pipelike alkaline intrusion, was emplaced into Archaean granitic rocks of the northeast Kaapvaal Craton at about the same time as the Bushveld Complex. The Palabora Mine is a significant producer of phosphate, 
copper, vermiculite, titano-magnetite and a number of other commodities including gold, silver, platinum group elements, rare earth elements, uranium and thorium. The composition and age of emplacement of the Phalaborwa Complex suggests that it may have a genetic link to the Bushveld Complex.

The Great Dyke of Zimbabwe is a large, layered ultramafic to mafic igneous complex, consisting of four amalgamated boat-shaped, funnel-like intrusions. It averages $8 \mathrm{~km}$ in width, is $550 \mathrm{~km}$ long and bisects the craton in a north-northeasterly direction. The $2.54 \mathrm{Ga}$ Great Dyke contains the world's second largest resources and reserves of the PGEs after the Bushveld Complex.The mineralisation which is also associated with significant copper and nickel sulphides, occurs in a pyroxenite layer several metres thick that is present in the upper portion of the funnel shaped intrusions, in each of a number of discrete compartments along the strike of the dyke. The dyke also hosts significant amounts of high grade chromite occurring in a number of seams, or layers of chromitite, lying several hundred metres below the PGE horizon. These seams have a greater strike extent than the PGE-bearing horizons and have been fairly extensively mined, mainly from underground operations. Important high grade chromite deposits also occur in close proximity to the Great Dyke, notably at Shurugwe. In this instance, the chromite occurs in an older greenstone belt, and is of the podiform type.

\section{Iron Ore}

Iron ore has been mined for centuries on the African continent and used both for the manufacture of iron-age tools and as a pigment for paint used in art and self decoration. Deposits of variable size occur throughout the African continent, many situated at the sites of ancient workings. With the increase in demand for iron ore in the last decade, extensive exploration programmes have been undertaken, with resources and reserves having been estimated for several world class deposits. Major expansions of traditional iron ore deposits and the development of some new mines also took place following the unprecedented demand for iron. The bulk of the iron deposits occur in the older rock sequences of the Archaean greenstone belts and particularly the overlying Paleoproterozoic volcano-sedimentary sequences and basins of the cratons.

Banded iron formation-hosted high-grade (>60 wt\% iron [Fe]) hematite ore deposits in Paleoproterozoic sedimentary basins made up the bulk of the world's iron ore production of 3.1 billion tonnes in 2014 (USGS, 2015) and of its reserves. These deposits currently produce virtually all of South Africa's annual supply of $68 \mathrm{Mt}$ of high-grade hematite ore. South Africa was the seventh largest producer of iron ore in the world at the time of writing (USGS, 2015) and the size and variety of its BIF-hosted high-grade iron ore deposits are of global significance and high economic value. Studies of South Africa's deposits have also led to a better understanding of the geological setting and genesis of these ores that can be applied to other iron ore deposits in the world (see Smith and Beukes, this volume).

Banded iron formations in Archaean greenstone sequences, particularly in areas of structural disturbance where supergene enrichment has taken place, have given rise to a number of iron ore deposits in the Kaapvaal and Zimbabwe cratons and in the cratonic nuclei of the Greater Congo Craton. The Bomvu Ridge (Ngwenya) iron ore deposit (on the south eastern flank of the Barberton Greenstone belt in Swaziland), was mined in prehistoric times, some 40,000 years ago, for pigment and from the early 1960s, for some
30 years, by modern opencast methods, then again more recently from 2011 to 2014 (reprocessing of the existing mine dumps). Similar enriched banded iron formations in the greenstone belts of the central Zimbabwe Craton have been mined and a successful steel plant, now called the Zimbabwe Iron and Steel Company (ZISCO), was established in the 1960s. The deposits near Kwe Kwe and at Mt Buchwa are the most important.

Deposits of the Archaean iron belt of Cameroon, Republic of Congo, and Gabon are grouped into those north and south of the Francevillian basins, i.e. the northern Archaean Ntem Block (e.g. Nkout, Mbalam-Nabeba, Avima, Badondo and Belinga Projects) and the southern Archaean Chaillu Block (e.g. Mayoko-Moussondji, Mayoko and Zanaga) respectively. The iron deposits are associated with Archaean itabirites, interstratified with volcano-sedimentary greenstone belt successions. The more important deposits are those which have undergone supergene enrichment, with the primary deposits generally being of lower grade. Mineralisation is predominantly hematite, with accessory goethite and magnetite.

Projects in the Ntem Block, at various stages of exploration and development, have identified extensive resources (multi-billion tonne) in primary and supergene enriched banded iron formation, with typical grades of between $30 \%$ to $35 \% \mathrm{Fe}$ and $>60 \% \mathrm{Fe}$ respectively. The BIF mineralisation can outcrop for several tens of kilometres. The best known deposit from a historical perspective is the Belinga deposit in Gabon with an estimated mineral resource of over one billion tonnes at $>60 \% \mathrm{Fe}$ (historic estimate) (Martini et al., 2002). The Mbalam/ Mbarga-Nabeba deposit, which straddles the Cameroon-Republic of Congo border, has combined Ore Reserves of $517 \mathrm{Mt}$ at $62.2 \% \mathrm{Fe}$ (Sundance Resources, 2015). Other deposits include: Belinga Sud, Mebaga, Kango North, Batoala, Boka Boka, Minkebe, and N'gama in Gabon; Ntem, Nkout, Binga, Djadom, Mamelles, Lele, and Bikoula in Cameroon; and Avima (690 Mt at 58\% Fe) (Core Mining, 2012), Badondo, and Youkou in the Republic of Congo (Figure 1b).

The main iron ore projects within the Chaillu Block, characterised by significant primary BIF resources with components of higher grade oxidised mineralisation, include the Zanaga, Mayoko, and the Mayoko-Moussondji Projects. In this region, BIF mineralisation outcrops for several tens of kilometres (de Waele et al., 2015).

In West Africa, the iron deposits of the Man Craton occur mainly within the greenstone belts of the Archaean basement, overlying Palaeoproterozoic volcano-sedimentary successions, and late Neoproterozoic mineralisation, related to the Rokelide Orogen, in Liberia, Guinea, Côte d'Ivoire and Sierra Leone (de Waele et al., 2013). Significant enriched iron ore deposits have been mined and are being investigated in banded iron formation in the eastern part of the Kénéma-Man Craton in Liberia. The Nimba Mountains, which traverse Liberia and Guinea, host a number of significant iron ore deposits including Tokadeh in Liberia, which has attracted the largest mining investment since the civil war. The Tokadeh mine, together with the Gangra and Yuelliton deposits, form part of the Western Range Project with a mineable resource estimate of $320 \mathrm{Mt}$ at $50 \% \mathrm{Fe}$ and an additional 2,000 Mt resource at 40\% Fe (Kukielski, 2010). Other deposits in Liberia include the Bomi Hills, Mano River, Bea Mountain, Mofe Creek, Mt Ginka, and Bong in Liberia (Figure 1b).

The Kalia deposit (Archaean BIF) in Guinea has an oxide mineral resource of $124.2 \mathrm{Mt}$ at $53.5 \% \mathrm{Fe}$. In Guinea, the Simandou range consists of a sequence of deformed itabirites, phyllites and quartzites within Proterozoic basement rocks. At Pic de Fon and Oueleba 
(Simandou), the itabirites have been enriched to form hematite and hematite-goethite mineralisation. The Simandou deposit is considered the largest undeveloped iron ore resource in the world with a probable ore reserve of $1,844 \mathrm{Mt}$ at an average grade of $65.5 \% \mathrm{Fe}$ and an estimated mineral resource of $835 \mathrm{Mt}$ at an average grade of $65.0 \%$ Fe (RioTinto, 2014, 2015). There has been some debate as to whether the iron ore deposits are Archaean or Palaeoproterozoic in age (Billa et al., 1999).

The Archaean Tonkolili deposit with an estimated 12.8 billion tonnes of iron rich duricrust, saprolite along with magnetite mineralisation (African Minerals, 2010) and the Neoproterozoic Marampa iron ore deposit of Sierra Leone, are important resources due for development when the present mining cycle improves.

In the Tiris Region of northern Mauritania, both hematite and magnetite deposits are mined from Archaean and Palaeoproterozoic successions of the Reguibat Shield. The main hematite deposits currently being mined are TO14 (Kédia) and M'Haoudat, which account for $60 \%$ of the total iron ore produced by the Société Nationale Industrielle et Minière de Mauritanie (SNIM). The Guelb El Rhein deposit is the only magnetite deposit currently being mined and it contains several hundred million tons of proven reserves, at an average grade of $\sim 37 \%$ Fe (SNIM, 2013) (Figure 1b).

Some of the world's biggest iron ore deposits occur in distinctive Palaeoproterozoic sedimentary basins which were deposited on a stable, cratonic granite-greenstone basement. The Transvaal Basin of the Kaapvaal Craton is an example of such a basin and it hosts the huge Sishen and Thabazimbi deposits of South Africa. The iron ore occurs at the top of a thick sequence of dolomites, with chert rich and chert poor formations and with well-developed stromatolite structures in places (Smith and Beukes, this volume).

In southwestern Gabon, the Tchibanga deposit is a Neoproterozoic banded iron formation. Mineralisation is associated with fine-grained hematite and goethite. Significant high grade mineralisation in the form of canga (a surface enriched secondary iron ore type of mineralisation), grading at an average of $45.2 \% \mathrm{Fe}$, has been delineated over a surface area of $1.95 \mathrm{~km}^{2}$ (Iron Ridge Resources, 2015).

Younger important iron deposits are known from Algeria and include deposits of the North African Palaeozoic Ironstone Belt which extends from Libya to western Sahara and which contains a number of identified sedimentary iron ore deposits of Ordovician to Devonian age, e.g. Gara Djebilet (1.7 billion tonnes at a grade of $57 \% \mathrm{Fe}$ ) (Taib, 2009) and Mechri Abdelaziz. Iron deposits, which are currently being exploited, are also known from younger Mesozoic sedimentary successions in Algeria, for example Ouenza (120 to $150 \mathrm{Mt}$ of 53\% Fe to $60 \% \mathrm{Fe}$ ) and Bou Khrada (Porter, 2005).

\section{Manganese}

Africa hosts just over 80 percent of the world's known land-based resources of manganese metal and produced some 41.1 percent of the 18 million tonnes of manganese metal contained in ores that were mined during 2014 (Beukes et al., this volume). The deposits are mainly of sedimentary and supergene origin comprising four major types, namely banded iron formation (BIF)-hosted, black shale-hosted, oolitic and supergene/karst-hosted types. The BIF-hosted Kalahari Manganese Field (KMF) is by far the largest of these deposits with some 4,200 million tonnes of manganese metal that represents about 77 percent of the world's known land-based resource. Large, black shale-hosted deposits are represented by those of the Francevillian succession in Gabon, the Nsouta in the Birimian succession of West Africa and the Kisenge district of the DRC. They typically consist of supergene manganese oxide ores capping 2.2-2.0 Ga manganese carbonate-bearing black shale protores. Significant karst-hosted deposits are represented by the $\sim 2.0 \mathrm{Ga}$ Postmasburg Manganese Field in South Africa and the Cretaceous Imini district in Morocco. The $1.9 \mathrm{Ga}$ Tolwe manganese deposit in South Africa is the only oolitic deposit from which some minor production has come in the past (Beukes et al., this volume).

\section{Nickel}

The nickel deposits of Africa occur mainly in the cratonic nuclei, although the intrusive mafic-ultramafic rocks of this recently defined east African nickel belt are considered to be part of a young Mesoproterozoic age, Kibaran, igneous event (Evans et al., this volume). Nickel mineralisation is almost invariably associated with copper and Platinum Group Elements (PGEs), in varying concentrations. Secondary nickel deposits in the form of concentrations in laterite, also occur in certain tropical areas of Africa. Nickel mining in Africa takes place principally in Botswana, South Africa and Zimbabwe, with much of the South African and Zimbabwean production being a by-product of the platinum-group element mining in the Bushveld Complex and Great Dyke. Several large nickel deposits have been discovered elsewhere in Africa but, until recently, their development has been hindered by political risk and limitations in energy and transport infrastructure.

\section{Nickel in Archaean Cratonic Nuclei}

The greenstone belts of the Zimbabwe Craton are hosts to nine important nickel ore bodies (with the Trojan, Empress and Shangani mines being the largest), most of which have similarities to the Kambalda type nickel deposits of the Yilgarn Craton of Western Australia. Massive, as well as disseminated nickel copper sulphide ore bodies, often associated with PGEs, occur in a range of mafic and ultramafic rock types generally with komatiitic affinities. In some instances mineralisation is associated with the basal portions of komatiitic flows or komatiitic intrusions of the lowermost Sebakwaian group, while in other instances mineralisation is hosted in gabbroic intrusions. The genetically comparable Selebi-Phikwe nickel copper deposit in Botswana occurs in the Limpopo metamorphic mobile belt which separates the Kaapvaal and Zimbabwe Cratons. It is likely that the Selebi-Phikwe orebody occurs in metamorphosed mafic rocks of the craton.

The world class Nkomati nickel deposit is situated in a linear zone of differentiated mafic rocks that lies well within the floor rocks of the eastern lobe of the Bushveld Complex. Magmatic segregation has taken place within this intrusion and nickel copper sulphides have been concentrated, both as massive ore bodies at and in the immediate footwall, as well as in large disseminated ore bodies in mafic rocks where they are associated with abundant chromite. Circular pipe like bodies of mafic material intrusive into the lower portion of the western limb of the Bushveld Complex to the west of the Pilanesberg, also contain both massive and disseminated nickel copper sulphide mineralisation.

In northern Tanzania, the Dutwa nickel laterite deposit occurs in the Archaean Kilimafedha greenstone belt of the Lake Victoria 
Goldfields. The greenstones are intruded by several large ultramafic bodies of possible Palaeoproterozoic age. In a number of instances surficial nickel laterites have formed on top of these bodies. The Dutwa deposit has an estimated mineral resource of approximately $106 \mathrm{Mt}$ @ 0.93\% Ni (Blackdown Resources, 2013).

\section{Mobile Belts}

Nickel deposits of the recently explored East African nickel belt occur in mafic to ultramafic intrusive rocks straddling the western boundary of the Archaean Tanzanian Craton and two Paleoprotezoic mobile belts to the west. Younger Paleoproterozoic to Mesoproterozoic metasedimentary rocks overlie the mobile belts and were intruded by the nickel-bearing ultramafic rocks between 1350 to $1400 \mathrm{Ma}$. Sulphide deposits including Kabanga, occur in small ultramafic intrusives in the northern sector of the belt, while the southern sector hosts sulphide and laterite mineralisation such as that of the Kapalagulu layered intrusion and smaller intrusions. The central sector contains only lateritic deposits. The main Kabanga ore body has a resource of $21 \mathrm{Mt}$ grading $1.0 \% \mathrm{Ni}$, while some of the smaller deposits such as Luhuma and Rujungu, have yielded grades in massive sulphide of $1.1 \% \mathrm{Ni}$ over $8.4 \mathrm{~m}$ and $0.7 \% \mathrm{Ni}$ over $7 \mathrm{~m}$ respectively (Evans et al., this volume).

The Ntaka nickel sulphide deposit in southern Tanzania is hosted in an ultramafic intrusion of unknown age, emplaced into metamorphosed volcanic and sedimentary sequences of the late Proterozoic Mozambique Belt. The deposit has estimated measured and indicated mineral resources of $12.8 \mathrm{Mt}$, at grades of $1.21 \% \mathrm{Ni}$ and $0.25 \% \mathrm{Cu}$; and inferred mineral resources of $45.0 \mathrm{Mt}$, at grades of $0.3 \% \mathrm{Ni}$ and $0.07 \% \mathrm{Cu}$.

\section{Copper, Cobalt, Lead, Zinc and Associated Minerals}

These base metals and associated minerals are mainly associated with Proterozoic mobile belts, although some important deposits also occur in cratonic areas.

\section{Palaeoproterozoic sedimentary basins}

\section{Zinc-lead-(fluorite) in the Transvaal Supergroup, South Africa}

The Neoarchaean to Palaeoproterozoic Transvaal sedimentary basin (Supergroup) overlies the Archaean Kaapvaal cratonic nucleus of the Kalahari Craton. In the Ghaap Plateau of the Griqualand West sub-basin, zinc-lead-(fluorite) has been mined in the past at the Pering and Bushy Park deposits. They constitute the oldest known Mississippi Valley-type (MVT) carbonate-hosted lead-zinc province in the world. The Pering deposit was the largest in the district, with an initial resource of $18 \mathrm{Mt} @ 3.6 \% \mathrm{Zn}$ and $0.6 \% \mathrm{~Pb}$ (Gutzmer, 2006).

\section{Copper-Silver, Lead-Zinc in the Magondi Belt, Zimbabwe}

The Palaeoproterozoic Magondi Supergroup (circa 2.1-2.0 Ga) was deposited on the western flanks of the Archaean Zimbabwe Craton. It was deformed and metamorphosed at 2.0-1.97 Ga during the Magondi Orogeny (Master et al., 2010). The Deweras and Lomagundi Groups contain several stratabound sediment-hosted $\mathrm{Cu}-\mathrm{Ag}$ deposits, including Mangula and Norah, which constitute the Magondi Copperbelt (Master, 1991). Other deposits in this belt include the Alaska, Shackleton, Shamrocke, Avondale and Angwa, mines. The Piriwiri Group hosts sedimentary exhalative massive sulphide $\mathrm{Cu}-\mathrm{Zn}-\mathrm{Pb}-\mathrm{Ag}$ deposits, which have been mined at Sanyati. All these deposits are structurally complex, having undergone polyphase deformation and greenschist to amphibolite-grade metamorphism. Most of the mines, which were historically active between 1957 and 2001, are now defunct.

\section{Copper-cobalt deposit in the Ruwenzori Belt}

The Buganda Group of Uganda occurs within the Palaeoproterozoic Ruwenzori Belt, on the northern margin of the Archaean Tanzanian craton. The Buganda Group is a volcano sedimentary succession, metamorphosed at amphibolite grade, and dated at 2.16$2.06 \mathrm{Ga}$ (Master et al., 2013). It hosts the Kilembe Cu-Co deposit which occurs on the flanks of the Ruwenzori Mountains. Kilembe is regarded as a structurally complex, Besshi-type massive sulphide deposit, consisting of massive chalcopyrite, pyrrhotite and cobaltiferous pyrite layers, intercalated with metasedimentary and metavolcanic rocks (Master et al., 2013). Although the Kilembe mine operated from 1956 to 1978, in the last two decades, the cobaltiferous pyrite stockpiles were treated using a bioleach process, to produce cobalt.

\section{Mesoproterozoic provinces (1600-1000 Ma)}

\section{Namaqua Province}

In southern Africa, the Mesoproterozoic Namaqua metamorphic complex contains various granitoid rocks dated at between $1200 \mathrm{Ma}$ and $1000 \mathrm{Ma}$, which have intruded older Palaeoproterozoic to Mesoproterozoic gneisses and metasediments. Within the Namaqua belt, the most important mineral deposits occur in Bushmanland, in the Northern Cape Province of South Africa. They include the large Aggeneys and Gamsberg zinc-lead-copper-silver massive sulphide orebodies of central Bushmanland. The deposits occur in a sequence of dominantly metasedimentary rocks with some volcanics. Aggeneys is a lead, zinc, copper and silver ore body, while Gamsberg is dominantly a zinc ore body with minor amounts of lead. A number of similar, smaller deposits occur in the area and all are thought to be of sedimentary exhalative genesis. The Prieska and Areachap copperzinc deposits, which lie further east, close to the boundary with the Kaapvaal Craton, are considered to be of volcano sedimentary origin.

Granitic intrusions and high grade metamorphism in Bushmanland, have resulted in the formation of numerous corundumsillimanite ore bodies. Muscovite, spodumene, as well as tungsten and tin, have been mined from two pegmatite belts in the province, while low grade uranium mineralisation is common in granites, pegmatites and younger sediments. The Steenkampskraal monazite deposit is one of the largest and highest grades of its kind in the world.

A younger event in the metallogenic evolution of this subprovince was the emplacement into characteristic "steep structures", at about $1100 \mathrm{Ma}$, of copper bearing noritoid bodies of the O'okiep district. While ancient copper mining took place in Namaqualand, it was also 
the site of the earliest modern mining in South Africa in the midNineteenth Century, and mining continued until the late Twentieth Century.

\section{Mozambique Belt in northern Mozambique}

The Mozambique Belt in northern Mozambique consists predominantly of various high-grade gneissic terranes aged between circa 1100 and $970 \mathrm{Ma}$, with some older components. They constitute a mega-nappe which was thrust over the circa 1140-1120 Ma Nampula Block, along the Lurio shear zone, during Pan-African Himalayanstyle continent-continent collision (Grantham et al., 2008). This thrusting was accompanied by Pan-African granite magmatism and the emplacement of the extensive pegmatite field north east of Vila de Mocuba. The pegmatites, which occur in the basement orthogneisses and in metasedimentary and metavolcanic paragneisses, have yielded a large variety of gemstones as well as large amounts of tantalite and microlite. The pegmatites also contain rare earth elements as well as uranium. The Tete metagabbro-anorthosite mass contains significant bodies of vanadium-bearing titanomagnetite which could be economically exploited. Coarse-grained anorthosite with attractive labradorite crystals from the Tete Complex has been quarried recently for dimension stone.

\section{Late Mesoproterozoic to Neoproterozoic sedimentary basins}

\section{Rehoboth Subprovince and Kalahari Copperbelt}

The Rehoboth Subprovince is situated on the northeastern flank of the Kalahari craton, in central Namibia. It contains magmatic arc rocks dated at circa $1.2 \mathrm{Ga}$, which contain subeconomic porphyrytype $\mathrm{Cu}$ deposits, such as Damas. Overlying the arc rocks is the Tsumis Group of the Sinclair Supergroup which extends northeast for hundreds of kilometres into Botswana, where it is known as the Ghanzi Group (Lehmann et al., 2015). The Tsumis and Ghanzi Groups are hosts to stratabound sediment-hosted copper-silver deposits that constitute the Kalahari Copperbelt. The belt is $1,000 \mathrm{~km}$ long and up to $250 \mathrm{~km}$ wide, and was deformed during the Neoproterozoic Damara orogeny. The Kalahari Copperbelt in Namibia, includes the Klein Aub, Oamites and Witvlei deposits, while in Botswana it includes the new Boseto mine, and several advanced stage exploration projects (Lehmann et al., 2015) (Figure 2).

\section{Central African Copperbelt}

The Central African Copperbelt of Zambia and the Democratic Republic of Congo (formerly Zaire), is one of the greatest mineralised regions in the world containing some of the largest and richest copper, cobalt and uranium deposits. These deposits are hosted mainly by metasedimentary rocks of the Neoproterozoic Katanga Supergroup, which is thus the most economically important stratigraphic entity in Central Africa. In addition to the copper-cobalt and uranium deposits, there are also major deposits of lead-zinc-copper ( \pm gallium $(\mathrm{Ga})$ and germanium $(\mathrm{Ge})$ ), nickel and iron hosted by Katangan rocks.

The Katanga Supergroup is a Neoproterozoic metasedimentary sequence which consists of the Roan, Nguba, Kundelungu, Fungurume and Biano Groups. The lowermost Roan Group, which contains most of the stratiform $\mathrm{Cu}$-Co mineralisation, was deposited after circa $880 \mathrm{Ma}$ (Armstrong et al., 2005), and is subdivided into the mainly siliciclastic Lower Roan Subgroup, and the mainly dolomitic and evaporitic Upper Roan Subgroup.

The Katanga Supergroup contains the world's greatest concentration of copper found in sediment-hosted stratabound copper deposits of approximately 185 million metric tons, which constitutes half of the total world copper resource hosted in sedimentary rocks (Zientek et al., 2014). It also contains the largest resource of cobalt. These deposits, known as the Central African Copperbelt, occur in a $600 \mathrm{~km}$-long arcuate trend, called the Lufilian Arc, which extends from the southeastern part of the Democratic Republic of the Congo (DRC), to Zambia. The part of the trend within the DRC is referred to as the Katangan or Shaban Copperbelt (with around $85 \mathrm{Mt}$ mined and proven resources, dominated by the Kamoa, Kolwezi and TenkeFungurume deposits); the part in Zambia is called the Zambian Copperbelt (with 25 proven deposits, having a total of about $100 \mathrm{Mt}$ $\mathrm{Cu}$ ). The recently discovered Kamoa deposit, on the extreme western edge of the Lufilian arc, west of Kolwezi in the Katanga province of the DRC, is one of the world's largest copper deposits, containing $800 \mathrm{Mt} @ 2.5 \% \mathrm{Cu}$, or $20 \mathrm{Mt} \mathrm{Cu}$ (Schmandt et al., 2013). Another major $\mathrm{Cu}-\mathrm{Co}$ deposit in the Katangan Copperbelt is Tenke-Fungurume, with an estimated resource of $547 \mathrm{Mt}$ ore @ 3.5\% Cu and $0.27 \% \mathrm{Co}$ (Shuh et al., 2012; Hitzman et al., 2012). The classic deposits of the Zambian Copperbelt are Nchanga-Chingola, Konkola, Mufulira, Chambishi, Nkana, Chibuluma, Baluba, Luanshya and Bwana Mkubwa. Many of these mines are now worked out and others are nearly exhausted. The Konkola Deep and Konkola North deposits represent the future of copper mining in the Zambian Copperbelt.

The Katanga Supergroup was deformed and metamorphosed during the Pan-African Zambezi and Lufilian orogenies, at between 600 and $480 \mathrm{Ma}$. Metamorphism in the Zambian Copperbelt was mainly of greenschist facies. In the Domes area to the west of the Copperbelt, amphibolite facies assemblages are recognised. This region hosts the important giant Lumwana $\mathrm{Cu}-(\mathrm{U})$, Trident $\mathrm{Ni}-(\mathrm{Cu}$, $\mathrm{Co})$ and Kansanshi $(\mathrm{Cu}, \mathrm{Au})$ deposits, which constitute what has been dubbed the "Western Copperbelt" of Zambia.

\section{Mineralisation}

The sediment-hosted, stratabound copper deposits of the Central African Copperbelt in Zambia and Katanga consist of fine-grained, $\mathrm{Cu}, \mathrm{Cu}-\mathrm{Fe}$, and $\mathrm{Cu}-\mathrm{Co}$ minerals, that form stratabound to stratiform disseminations in siliciclastic or dolomitic metasedimentary rocks of the Katanga Supergroup. Chalcocite and bornite, carrollite and chalcopyrite typically make up the primary ore zones. The ore minerals occur as cements, replacements, and as veinlets. Some important deposits, such as Kansanshi, are not stratiform, but vein type. The ores have been oxidized under tropical conditions, and the secondary ore minerals consist of malachite, chrysocolla and heterogenite. In addition to $\mathrm{Cu}-\mathrm{Co}$ deposits, the Central African Copperbelt also hosts major $\mathrm{Zn}-\mathrm{Pb}-\mathrm{Cu}-\mathrm{Ga}-\mathrm{Ge}$ polymetallic deposits, of which the most important are the Kipushi deposit in the DRC and the Kabwe deposit in Zambia. In the Kafubu area of the Zambian Copperbelt, basement schists host the world's second largest emerald district after Colombia (Zwaan et al., 2005).

The vast literature on the Copperbelt, from the 1890s to the mid 1990s was documented in the comprehensive bibliography of Master (1997). Since then, a new golden era has dawned, following the ending of state monopolies in mining and research in both the DRC and 
Zambia. The new exploration and mining rush by private enterprise has led to a boom in research, resulting in new insights into the formation of the $\mathrm{Cu}-\mathrm{Co}$ and uranium deposits in this world-class district. The results of multidisciplinary studies in the Zambian and Congolese (Katangan) Copperbelts, have been summarized in several key papers and special volumes which have appeared in the past eleven years (Robb et al., 2005; Selley et al., 2005; Hitzman et al., 2012). Haest and Muchez (2012) provided a review of both stratiform and vein-type mineralisation $(\mathrm{Cu}-\mathrm{Co}, \mathrm{Cu}-\mathrm{Ag}$ and $\mathrm{Zn}-\mathrm{Pb}-$ $\mathrm{Cu}-\mathrm{Ag}$ ) in the Central African Copperbelt, as well as in the Damara Belt of Namibia. Detailed reviews of the Central African Copperbelt, its $\mathrm{Cu}$-Co deposits and exploration potential, were published by Taylor et al. (2013) and Zientek et al. (2014). The uranium mineralisation in the Katangan belt has mainly been studied mineralogically over the past century, but the processes leading to the formation of uranium deposits have received attention recently and have been reviewed by Eglinger et al. (2013), and by Kinnaird and Nex (this volume).

\section{Iron-oxide-copper-gold deposits in Neoproterozoic mobile belts}

There are a number of occurrences of granitic intrusion-related iron-oxide-copper-gold (IOCG) deposits in various Pan-African mobile belts in Africa. Within the Katangan metallogenic province in Zambia, the Katangan sedimentary rocks, which host $\mathrm{Cu}-\mathrm{Co}$, were intruded by granites during the Pan-African Lufilian orogeny, at around $550 \mathrm{Ma}$. Associated with the intrusive granites, there are numerous $\mathrm{Cu}-(\mathrm{Ag}, \mathrm{Au}, \mathrm{Pb}, \mathrm{Zn})$ occurrences in the surrounding metasedimentary rocks, among which is the large Kitumba deposit, identified as an IOCG deposit, with an Indicated Resource (by 2013) of $87.6 \mathrm{Mt} @ 1.17 \% \mathrm{Cu}$ (0.5\% Cu cutoff) (Robertson, 2013). Other IOCG deposits in Pan-African belts include the Guelb Moghrein Cu$\mathrm{Au}$ deposit near Akjoujt in the Mauritanide belt, Mauritania (with 26.36 Mt @ 1.26\% Cu, 0.87 g/t Au, First Quantum Mining, 2011), and the Hofrat-en-Nahas $\mathrm{Cu}-\mathrm{Au}-(\mathrm{U})$ deposit in South Sudan, with reserves of $20 \mathrm{Mt} @ 5.9 \% \mathrm{Cu}$ (Yao and Master, 2001).

\section{Mesozoic to Miocene lead-zinc-silver deposits of the Alpine Orogeny}

The Jurassic carbonate platform of northeastern Morocco and northwestern Algeria is host to in excess of 100 Mississippi Valleytype (MVT) lead-zinc occurrences, varying from small uneconomic occurrences to major districts. In Morocco, the Touissit-Bou Beker district with estimated combined production and reserves of more than $70 \mathrm{Mt}$ at an average grade of $4 \% \mathrm{~Pb}, 3.5 \% \mathrm{Zn}, \sim 1 \% \mathrm{Cu}$ and $120 \mathrm{~g} / \mathrm{t} \mathrm{Ag}$, is considered to be one of the largest MVT districts in the world and accounts for a large portion of Morocco's total base metal production (Bouabdellah et al., 2012). Deposits which have and are being mined, include Mekta, Beddiane, Touissit, and Bou Beker in Morocco and El Abed in Algeria.

Further to the east in Tunisia, Triassic to Miocene carbonate sequences host abundant zinc-lead-barite-fluorite \pm silver deposits, including Fedj el Adoum (Fej Lahdoum), Bou Grine, Boujabeer, Hassine, Djebba, Djerissa, and Ouled Moussa. The deposits are generally classified as MVT deposits, with mineralisation cross-cutting host rocks ranging from Triassic to Miocene and Pliocene in age. The mineralising fluids appear to have exploited thrusts, regional northeast-southwest and northwest-southeast trending faults, salt diapirs and various unconformities (Bouhlel, 2005; Sheppard et al., 1996).

\section{Uranium, Tin, and Rare Earth Elements}

\section{Uranium}

Africa has been a significant world producer of uranium since 1945 when it was discovered in the Democratic Republic of the Congo and mined at Shinkolobwe, which provided 30,000 tonnes of uranium ore for the Manhattan Project to produce atomic bombs. Africa currently provides some $18 \%$ of the world's uranium (Kinnaird and Nex, this volume). There are four major types of deposits that produce the majority of the uranium in Africa: the Archaean quartzpebble-conglomerate hosted gold-uranium deposits of the Witwatersrand in South Africa; the Neoproterozoic end-orogeny sheeted leucogranites and small stocks of Namibia; the Mesozoic sandstone-hosted roll-front deposits of Niger and Malawi; and the recent, channel-hosted calcrete and alluvial deposits in Namibia.

\section{Tin}

Because of its hardening effect on copper, tin was used in bronze implements as early as $3500 \mathrm{BC}$, although the pure metal was not used until about $600 \mathrm{BC}$. Tin has been mined in Nigeria since the $9^{\text {th }}$ century with the famous Benin bronzes dating from the $13^{\text {th }}$ century. Significant volumes of tin production began in the $20^{\text {th }}$ century and maximum output from African deposits was reached in the 1970s. African deposits range in age from Archaean in Zimbabwe and Palaeoproterozoic in South Africa, to Mesozoic and Pleistocene in Nigeria (Kinnaird and Nex, this volume). Major eras of tin mineralisation are related to continental amalgamation at the end of the Proterozoic and these are represented in Neoproterozoic PanAfrican Belts in Namibia, Nigeria, Rwanda, Somaliland, and the DRC. In Mesozoic times cassiterite mineralisation was associated with granite magmatism related to the fragmentation of Gondwana. These deposits occur in Nigeria, Cameroon and Namibia. African tin deposits include disseminations in granite cupolas, lode-style mineralisation either as endogranitic or exogranitic veins, rare metal pegmatites, other veins not directly associated with granites, as well as in eluvial and alluvial deposits (Kinnaird and Nex, this volume).

\section{Rare Earth Elements}

Rare Earth Elements (REE) are vital to a wide range of modern high technology applications and the critical strategic role of REE to the economic development of the U.S.A., European Union and Japan, has been recognised. China holds a near monopoly over the supply of REE and REE products - accounting for around 95\% of the global supply in 2010. These factors triggered a rush to discover REE deposits and develop REE production outside of China.

At the beginning of 2015 there were 11 advanced REE projects on the African continent - projects on which formally defined resources had been published (Harmer and Nex, this volume). On average, the most REE-enriched magmatic rocks are carbonatites, followed by peralkaline granites and syenites. Enrichment of the REE to ore levels is the consequence of the incompatible behaviour of the REE during magmatic crystallisation and their limited solubility in 
low temperature aqueous solutions, making the REE largely immobile during weathering.

Enriching processes can be conveniently grouped, on the basis of the temperature range over which they operate, into Primary Magmatic, Magmatic/Hydrothermal and Epithermal. Even the most enriched igneous rocks require the action of one or more secondary processes to produce economically significant grades of the REE (Harmer and Nex, this volume).

\section{Coal, oil and gas}

\section{Coal}

Africa is host to coal deposits stretching from the far north to the far south and ranging in age from the Carboniferous through to the Miocene. Coal production in the north of the continent is however currently of a very limited nature compared to that in the south where, due mainly to its low cost and relative abundance, the commodity has long been the primary source of energy (Hancox, this volume). The coalfields of Africa and the Gondwanaland coal of South Central Africa (SCA) in particular, contain significant resources of both thermal and metallurgical coal.

All of Africa's coals are associated with non-marine to marginal marine terrestrial clastic sedimentary sequences and most commonly in the SCA, these are mudstones and sandstones assigned to the Karoo Supergroup and its spatial and temporal equivalents. Whilst the coals in the rest of Africa span the Carboniferous to Miocene, most SCA coals formed during two periods of time, one in the Early Permian and the other in the Middle-Late Permian. Unlike the Carboniferous coals from the northern hemisphere, SCA Permian coals generally have high Ash contents.

Geologically, the pre-Karoo (basement) tectonic framework exerts an important control on the geometry and development of the SCA Karoo Basins, as well as on the thickness of the sedimentary fill and coal seam characteristics. Historically, coal production in Africa has been the preserve of South Africa, which is by far the largest producer, utiliser and exporter of coal in the region. This has been augmented by far smaller scale production from Botswana, Zimbabwe, Zambia, southwestern Tanzania and Nigeria. More recently, Mozambique has become a producer as well, surpassing Zimbabwe in 2012, to become the second-largest coal producer in Africa.

Of the North African coals, economically the most important are the Cretaceous bituminous and sub-bituminous coals, known from Algeria, Benin, Egypt, Libya, Mali, Mauritania, Niger, Nigeria, Senegal, and Sudan. Nigeria has the most potential, with coal resources believed to be in excess of 4 billion tonnes, including Africa's largest deposits of lignite (Ohimain, 2014 from Hancox, this volume).

\section{Oil and Gas}

Africa currently produces some $7.0 \%$ of the world's oil and a similar amount of its gas, from a range of basins that include intracratonic sags and epicratonic embayments. In 2013, Africa held $7.7 \%$ of the world's known oil reserves and $7.6 \%$ of the world's gas reserves. Petroleum occurs throughout the stratigraphic column, extending from geographically widespread seepages in Recent sediments, to oil in fluid inclusions in the Late Archaean sediments of the Witwatersrand Basin (Selley and van der Spuy, this volume).

There is still great potential for future oil and gas discoveries in
Africa, especially offshore, as seismic, drilling and production technology constantly improve. There is also the potential for producing unconventional petroleum resources, both coal-bed methane from Karoo coals, and shale gas in parts of the Karoo Basin and in the North African source rocks of Algeria and Libya in particular.

In North Africa, post-Palaeozoic clastic sequences, ranging in age from Triassic to Cretaceous, have been deposited in a series of cratonic sag basins. Desultory petroleum exploration in North Africa throughout the early part of the last century accelerated with the discovery of the giant Hassi Messaoud oil field in Algeria, in 1953. With a reserve of 10 billion barrels, this is the largest oil field in Africa. The reservoir is the Cambro-Ordovician Hassaouna Sandstone, the source is Silurian Tannezuft shale and the seal comprises Triassic evaporates (Selley and van der Spuy, this volume).

In Libya the quest for similar fields in the Sirte Basin led to the discovery of late Cretaceous - Lower Eocene carbonate build-ups and shoals, followed by the discovery of reservoirs in Early Cretaceous sandstones in the Sarir, Messla and associated fields. Potential exists in the North African basins for tight gas production from deeply buried infra-Cambrian and Ordovician source rocks (Craig et al., 2005).

The gradual break up of Pangaea from north to south led to the formation of evaporites over a series of incipient rift basins along the coast of West Africa. Petroleum has been found in salt-related Cretaceous, Palaeogene and Neogene sandstone reservoirs in Mauritania and Senegal. In Congo, Angola and Gabon, petroleum is trapped in Tertiary submarine fan sands, in Cretaceous, carbonate reservoirs and in pre-salt lacustrine carbonates and turbidite sands (Selley and van der Spuy, this volume).

The Niger Delta occurs at the southern end of a major series of rifts extending from what is now the Atlantic Ocean to the modern Mediterranean and hosts the largest petroleum province of Africa. These rifts are of Cretaceous age and at one time allowed a continuous seaway to extend across the continent. Petroleum seeps have long been known along the margins of the East African rifts and significant reserves have been discovered in Kenya and Uganda, along the eastern margin of Lake Albert.

After earlier exploration for conventional hydrocarbons, the Karoo Basins are now rather regarded as holding potential for unconventional resources. The only production in South Africa has been from the Bredasdorp Subbasin of the Outeniqua Basin, off the south coast. Gas has been produced from these basins since the early 1990s.

\section{Industrial Minerals}

\section{Phosphate}

Five major types of phosphate resources are mined in the world, namely marine, igneous, metamorphic, biogenic and those resulting from weathering (Van Straaten, 2002). Sedimentary and igneous phosphate rocks occur throughout Africa, while metamorphic and marine deposits occur to a lesser extent. The phosphate rock resources are unequally distributed, with the major sedimentary deposits concentrated in northern and northwestern Africa, compared with a fairly limited distribution in sub-Saharan Africa.

In eastern and southern Africa, most of the phosphate resources are associated with igneous alkaline and carbonatite complexes, the most commercially significant being the Phalaborwa Complex in 
South Africa, which is the biggest resource of igneous phosphate rock currently being mined in Africa (Van Kauwenbergh, 2002). A huge resource of potentially economic phosphate rock in the form of apatite bearing gabbronorite, occurs in a number of layers in the 1,000 m thick upper zone of the Bushveld Complex. These layers can be traced over tens of kilometres in the northern, eastern and western lobes of the Bushveld Complex (Viljoen, this volume). Apatite-magnetite mineralisation also occurs in rocks unrelated to alkaline magmatism as in Ethiopia and Mozambique, and in apatite syenites in eastern and central Zambia.

Sedimentary phosphate deposits in Africa range from late Proterozoic to Pleistocene in age. North and northwest Africa have enormous reserves of sedimentary phosphate rock within the western section of the huge Tethyan phosphate province (Notholt $e t$ al.,1989), which extends into the Middle East. The northern edges of the Arabian-Nubian Shield were the site of intense phosphogenesis during Late Cretaceous to Eocene times and this area is believed to contain a large portion of the world's unexploited phosphate resources (Soudry et al., 2006). Morocco, Tunisia and Egypt are all major producers. Morocco has almost $85 \%$ of the known sedimentary phosphates in Africa, with resources estimated in excess of 65 billion tonnes (Notholt et al., 1989). In Morocco, phosphate was first discovered in 1908 and there are four major phosphate basins (Oulad Abdoun Basin, the central Ganntour Basin, the Meskala Basin and the Oued Eddahab Basin). Phosphate rocks of Eocene age are widely distributed in Tunisia and Algeria. Further deposits are known from Guinea Bissau, Mauritania, Senegal and Togo. In southern Africa, small sedimentary deposits are known from Angola and Tanzania.

\section{Potash}

Though potash is not presently mined in Africa the continent hosts significant deposits, particularly in the Congo Basin where three deposits are known to each host over a billion tonnes of potash ore, one seam of which is thought to be the highest grade potash deposit in the world (Pedley et al., this volume). Other significant deposits are known in the Danakil depression of Eritrea and Ethiopia. Less significant deposits are hosted in the Late Triassic evaporates of Morocco as well as in Libya, Tunisia and Algeria.

The onshore portion of the Congo Basin occupies a 150 kilometre long northwest-southeast oriented coastal strip within the Republic of Congo, extending from Gabon in the north to Cabinda (Angola) in the south. Potash was first identified in oil exploration wells in neighbouring Gabon in 1948 and the Saint Paul mine was developed at Holle and operated from 1969 to 1977, mining sylvinite ore. At peak production, approximately 450,000 tonnes of Muriate of potash were produced per year (MDPA, 1982).

The potash resources for the Mengo, Kola and Dougou deposits in the Congo are each over a billion tonnes and are open laterally. These deposits compare very favourably with sylvinite and carnallitite deposits globally, being of excellent grade, simple mineralogy, at relatively shallow depth, with simple geometry and having very low insoluble contents. If defined, a resource for seam 3/IX (Elemental Minerals' Hangingwall Seam), would probably be the world's highest grade potash deposit at close to $60 \% \mathrm{KCl}$. There is the potential to expand the Congolese deposits significantly. It is probable that between 30 and 100 billion tonnes of Carnallite, grading over 18 percent $\mathrm{KCl}$, are present within the onshore portion of the Congo
Basin of between 200 and 1,000 metres depth (Pedley et al., this volume).

The known potash deposits of northeast Africa occur in the evaporite sediments of the Danakil Depression in the Afar region of northeastern Ethiopia and southeastern Eritrea. The deposits, which were discovered in 1906, formed by evaporation of sea water in a previous arm of the Red Sea that was isolated by uplift of the Danakil Alps. Rock-salt-dominated Quaternary evaporite beds approximately $2 \mathrm{~km}$ thick, are known beneath the present Asale salt lake near Dallol, in the northern part of the Danakil Depression, about $120 \mathrm{~m}$ below sea level (Master, 2016).

Several large playa lakes (locally referred to as 'chotts') host ephemeral carnallite crusts and intercrystalline carnallite cements in their uppermost pan-facies sediments (Warren, 2005). The chotts are within a 1,000 kilometre-long 'belt' along the northeast extremity of the Algerian and Tunisian Sahara, and also extend into Morocco and Libya. The large Chott Djerid in Tunisia, is fed by springs and sheetfloods coming from the Atlas Mountains to the north, and its evaporites, which include halite and gypsum, formed by complete evaporation of lake waters in the dry season.

\section{Heavy mineral sands}

A number of heavy mineral sand deposits occur along the African coastline. They consist of concentrations of titanium minerals (rutile, ilmenite, leucoxene) and zircon, in fossil placers in young coastal sediments ranging in age from Pliocene to Recent (i.e., over the last $5 \mathrm{Ma})$.

Currently there are seven operating heavy mineral sand mines in Africa, with most production coming from South Africa (Richards Bay, Hillandale, Namakwa Sands). The other mines are located in Senegal, Sierra Leone, Mozambique and Kenya. A further thirty plus deposits are known but are considered economically marginal at present (Tyler and Minnitt, 2004; Esterhuizen, 2008; Van Gosen et al., 2014).

The deposits are generally large with several having resources of more than a billion tons. The total heavy mineral content (rutile, ilmenite, leucoxene and zircon) is variable, ranging between 2 and 12 percent. Some of the smaller deposits have higher grades, containing up to 40 percent total heavy minerals, whilst most of the large deposits, with tonnages in excess of $500 \mathrm{Mt}$ ore, run at a grade of more than 5 percent. The quantity of valuable minerals, i.e, zircon, rutile, ilmenite and leucoxene, together with the resource tonnages, determine the viability of a particular deposit.

Deposits are hosted mainly by young surficial unconsolidated, siliciclastic sands of marine-aeolian origin. They are generally related to extensive dune fields stretching for tens and in some cases more than a hundred kilometres parallel, or sub-parallel, to the present coastline and may occur proximal to the coast or several kilometres inland. They invariably lie close to major paleo-or present fluvial drainage systems. Most deposits vary in age from 5 Ma to the present and are commonly referred to as fossil placers. Recent dune fields also host heavy mineral sand deposits, while offshore, the continental shelf offers significant heavy mineral potential. Some high-grade deposits, like the large undeveloped Corridor Sands deposit in Mozambique, with more than a billion tons of ore, occur in older coastal dunes situated farther inland, which formed during earlier sea level transgressions.

Although African production of heavy minerals is currently second 
only to Australia, the potential exists for the continent to become the leading producer of titanium feedstock and zircon in the future (Tyler and Minnitt, 2004).

\section{Acknowledgements}

The authors would like to thank Heather Wilson for her cartographic input and Lynn Whitfield for improving and finalising the figures.

\section{References}

Abdelsalam, M.G., Liégeois, J.P. and Stern, R.J., 2002. The Saharan Metacraton. J. Afr. Earth Sci. 34, 119-136.

Adamas Intelligence, 2014. http://www.adamasintel.com/Previews/ REMO_Executive_Summary.pdf.

African Minerals, 2010. Tonkilili Iron oreProject Mineral Resource Estimate Update. Press release 16 December 2010. Accessed February 2016 on http://www.african-minerals.com/system/files/ press/ Tonkililiironoreprojectmineralresourceestimateupdate.pdf.

Armstrong, R.A., Master, S. and Robb, L.J., 2005. Geochronology of the Nchanga Granite, and constraints on the maximum age of the Katanga Supergroup, Zambian Copperbelt. J. Afr. Earth Sci., 42, 32-40.

Beukes, N.J., Swindell, E.P.W. and Wabo, H., (this volume). Manganese Deposits of Africa.

Billa, M., Feybesse, J.-L., Bronner, G., Lerouge, C., Milési, J.P., Traoré, S. and Diaby, S., 1999. Les formations à quartzites rubanés ferrugineux des Mons Nimba et du Simandou : des unités empilées tectoniquement, sur un <<soubassemenr 〉> plutonique Archéen (craton de Kénéma-Man), lors de l'origène Éburnéen. Comptes Rendus de l'Académiedes Sciences - Series IIA - Earth and Planetary Science 329(4):287-294.

Blackdown Resources Limited: Dutwa Project Resources, 2013.http:/ /www.blackdownresources.com/dutwa-resources.asp.

Bouabdellah, M., Sangster, D.F., Leach, D.L., Brown, A.C., Johnson, C.A. and Emsbo, P., 2012., Genersis of the Touissit-Bou Beker Mississippi Valley-Type District (Morocco-Algeria) and Its Relationship to the Africa-Europe Collision. Economic Geology 107, pp. 117-146.

Bouhlel, S., 2005. Carbonate-hosted Mississippi Valley-type Pb-Zn deposits in Tunisia (Eastern Atlasic belts). Proceedings of the $8^{\text {th }}$ Biennial SGA meeting, China 2005. Vol 3, pp. 19-22.

Brooke Pattrick Publications, 2014. African Mines Handbook 2014. Brooke Pattrick Publications, Johannesburg. 288 pp.

Brownfield, M.E. and Weaver, J.N., 1992. Paleogeography and stratigraphy of Cretaceous coal deposits of North Africa. Geological Society of America.

B2Gold, (2016). B2Gold Reserves and Resources. http:// www.b2gold.com/projects/reserves-resources/.

Centamin, 2015. Resources and Reserves - Sukari Total Mineral Resource as at 30 June 2015. Accessed February 2016 on http:// www.centamin.com/centamin/operations/resources-and-reserves.

Clifford, T.N., 1966. Tectono-Metallogenic units and Metallogenic Provinces of Africa. Earth and Planetary Science Letters, 1, 421434.

Core Mining, 2012. The Avima Project. Accessed February 2016 onhttp://www.coremining.com/index.php?option=com_content $\&$ view $=$ article \&id=3\&Itemid=3.

Craig, J., Grigo, D., Rebora, A., Serafini, G. and Tebaldi, J., 2005. From Neoproterozoic to Early Cenozoic: exploring the potential of older and deeper hydrocarbon plays across North Africa and the Middle East. In: Vining, B.A. and Pickering. (Eds) Petroleum
Geology: From Mature Basins to New Frontiers - Proceedings of the 6th Petroleum Geology Conference, DOI: 10.1144/ 0070673. The Geological Society, London. 673-705.

de Waele, B., Lacorde, M., and Rivers, J., 2015. Banded Iron Formations and associated Detrital Iron Deposits of the Western Congo Craton. Conference Paper, September 2015. SEG 2015, Hobart, Tasmania.

de Waele, B., Lacorde, M., Vergara, F., and Chan, G., 2013. New Insights on West African Tectonics and Iron Mineralisation Based on Zircon U-Pb SHRIMP Geochronology and Structural Mapping. Accessed February 2016 on http://www.bdewaele.be/ pdfs/P1_19.pdf.

de Wit, M.C.J., Bhebhe, Z.M., Davidson, J.M., Haggerty, S., Hundt, P., Jacob, R.J., Lynn, M.D., Marshall, T.R., Skinner, C.P., Smithson, K., Stiefenhofer, J., Roberts, M.A., Revitt, A., Spaggiari, R.I. and Ward J.D.,(this volume). Overview of Diamond Resources in Africa.

Eglinger, A., Andre-Mayer, A., Vanderhaeghe, O., Mercardier, J., Cuney, M., Decree, S., Feybesse, J. and Milesi, J., 2013. Geochemical signatures of uranium oxides in the Lufilian belt: from unconformity-related to syn-metamorphic uranium deposits during the Pan-African orogenic cycle. Ore Geology Reviews, 54, 197-213.

ENOR, 2012. Presentation entitled "Seeking a new Partner".Accessed February 2016 onhttp://enor.dz/documents/presentation-enor.pdf.

Evans, D.M., Hunt, J.P.P.M. and Simmonds, J.R., (this volume). An overview of nickel mineralisation in Africa with emphasis on the Mesoproterozoic East African Nickel Belt (EANB).

First Quantum, Mauritanian Copper Mines (MCM), 2011. Guelb Moghrein copper-gold mine, Mauritania. Accessed February 2016 onhttp://www.first-quantum.com/Theme/FirstQuantum/files/ doc_downloads/Guelb_Moghein_FactSheet.pdf.

Fockema, P.D., 1986. The heavy mineral deposits north of Richards Bay. In: Anheusser, C.R. and Maske, S. (Eds.), Mineral Deposits of Southern Africa II, G.S.S.A., Johannesburg, 2301-2307.

Foster, R.P., Mann, A.G., Stowe, C.W. and Wilson, J.F., 1986. Archaean gold mineralization in Zimbabwe: in Anhaeusser C.R., Maske, S., (Eds), 1986, Mineral Deposits of South Africa Geol.Soc. South Africa, Johannesburg v1 pp 43-112.

Grantham, G.H., Macey, P.H., Ingram, B.A., Roberts, M.P., Armstrong, R.A., Hokada, T., Shiraishi, K., Bisnath, A. and Manhica, V., 2008. Terrane correlation between Antarctica, Mozambique and Sri Lanka; comparisons of geochronology, lithology, structure and metamorphism and possible implications for the geology of southern Africa and Antarctica. Geol. Soc., Lond., Spec. Publ. 308, 91-119.

Gribble, P., Melnyk, J. and Munro, P., 2013. Bisha Mine Eritrea, Africa. NI 43-101 Technical Report. Prepared for Nevsun Resources Ltd, effective date 31 December 2013. 328 pp. Accessed February 2016 onhttp://www.nevsun.com/pdf/ Nevsun_TechReport-Bisha_Mine_2014.pdf.

Groves, D.I.,2015. Emergence of the Western Arabian-Nubian Shield as an exploration destination with emphasis on the Mato Bula gold-rich VMS system discovery. Accessed February 2016 on http://www.cet.edu.au/secure-pdf/3 david groves_dday2015.pdf.

Gutzmer, J., 2006. The Paleoproterozoic carbonate-hosted Pering Zn$\mathrm{Pb}$ deposit, South Africa: I. Styles of brecciation and mineralization. Mineralium Deposita (2006) 40: 664-685.

Haest, M. and Muchez, P., 2012. Stratiform and vein-type deposits in the Pan-African Orogen in Central and Southern Africa: evidence for multiphase mineralization. Geologica Belgica, 14(1/2), 2344.

Hancox, P.J., (this volume). The Coalfields of south-central Africa: a current perspective. 
Harmer, R.E. and Nex, P.A.M., (this volume). Rare Earth Deposits of Africa.

Henckel, J., Poulsen, K.H., Sharp, T. And Spora, P., (this volume). Lake Victoria Goldfields.

Hitzman, M.W., Broughton, D., Selley, D., Woodhead, J., Wood, D. and Bull, S., 2012. The Central African Copperbelt: Diverse Stratigraphic, Structural, and Temporal Settings in the World's Largest Sedimentary Copper District. Sillitoe Volume, Society of Economic Geologists, Inc., Special Publication, 16, 487-514.

IronRidge Resources, 2015. New high-grade mineralisation discovered. Press release, 23 November 2015. Accessed February 2016 on http://ironridgeresources.com.au/userfiles/2015.11.23 $\% 20-\% 20 \% 20 \mathrm{New} \% 20 \mathrm{High}-\mathrm{Grade} \% 20$ Mineralisation\% 20Discovered\%20(PDF).pdf.

Johnson, P.R., 2016. Tectonics and Mineral Deposits of the ArabianNubian Shield: Base-Metals and Gold in Earth's Largest Mineralized Neoproterozoic Crustal Block. Abstract accessed February 2016 on http://www.arizonageologicalsoc.org/event2092809.

Karmakar, S. and Volker Schenk, V., 2015. Neoproterozoic metamorphic events along the eastern margin of the East Sahara Ghost Craton at Sabaloka and Bayuda, Sudan: Petrology and texturally controlled in-situ monazite dating. Precambrian Research, 269, 217-241.

Kennedy, W.Q., 1964. The structural differentiation of Africa in the Pan-African ( \pm 500 my) tectonic episode. Research Institute of African Geology, Eighth Annual Report of Scientific Results 1962-63, 48-49.

Kinnaird, J.A., Nex, P.A.M. and Milani L., (this volume). Tin in Africa. Kinnaird, J.A. and Nex, P.A.M., (this volume). Uranium in Africa.

Kukielski, P., 2010. Building a world-class mining business, ArcelorMittal Investor Day 2010 - 16 September - London and New York. Accessed February 2016 on http://corporate. arcelormittal.com/ /media/Files/A/ArcelorMittal/investors/ presentations/investor-days/2010/627-48-3-0-InvestorDay2010Presentation-Pkup.pdf.

Lawley, C., Selby, D. and Imber, J., 2013a. Re-Os Molybdenite, Pyrite, and Chalcopyrite Geochronology, Lupa Goldfield, southwestern Tanzania: Tracing Metallogenic Time Scales at Midcrustal Shear Zones Hosting Orogenic Au Deposits. Economic Geology, 108(7), 1591-1613.

Lawley, C., Imber, J. and Selby, D., 2013b. Structural Controls on Orogenic Au Mineralization During Transpression: Lupa Goldfield, southwestern Tanzania. Economic Geology, 108(7), 1615-1640.

Lehmann, J., Master, S., Rankin, W. and Kinnaird, J., 2015. New correlations and tectonic setting of the Kalahari Copperbelt in Namibia and Botswana. Ore Geology Reviews, 71, 169-190.

Martini, J.E.J., Makanga, J.F., Gnangamoukoula, D. and Ngakoussou Appana, F., 2002. Carte métallogénique de la République Gabonaise 1:1 000000 : Notice explicative, South African Council for Geoscience. 169pp.

Master, S., 1991. Stratigraphy, tectonic setting, and mineralization of the early Proterozoic Magondi Supergroup, Zimbabwe: a review. Economic Geology Research Unit Information Circular No. 238, Department of Geology, University of the Witwatersrand, Johannesburg, $75 \mathrm{pp}$.

Master, S., 1997. Bibliography of the geology and mineral resources of the Central African Copperbelt and the Katangan Sequence in Zambia, Democratic Republic of Congo (Zaire), Angola and Zimbabwe (1830-1997). Africa Geoscience Review, 4(2), 177283.

Master, S., 2016. Gaet'ale- a new deadly spring (and potential tourist health hazard) in the Asale salt flats near Dallol, Danakil
Depression, Ethiopia. Journal of Applied Volcanology, 5(1), DOI 10.1186/s13617-015-0042-x.

Master, S., Bekker, A. and Hofmann, A., 2010. A review of the stratigraphy and geological setting of the Palaeoproterozoic Magondi Supergroup, Zimbabwe: type locality for the "Lomagundi" global carbon isotope excursion. Precambrian Research, 182(4), 254-273.

Master, S., Bekker, A. and Karhu, J.A., 2013. Palaeoproterozoic high $\delta^{13} \mathrm{C}_{\text {carb }}$ marbles from the Ruwenzori Mountains, Uganda: Implications for the age of the Buganda Group. Chemical Geology, 362, 157-164.

MDPA, 1982. Mines Des Potasse D'Alsace company communications. Unpublished Company report.

Mendelsohn, F. Ed., 1961. The geology of the Northern Rhodesian Copperbelt. MacDonald, London, 523 p.

Nanyaro,J.T., 1989. Proterozoic gold-base metal veins in the Mpanda mineral field, western Tanzania. Ann. Mus. roy. Afr. Centr., sér. IN-8 ${ }^{\circ}$, Sci. Géol., n 97, 144 pp.

Notholt, A.J.G., Sheldon, R.P. and Davidson, D.F. (Eds.), 1989. Phosphate Deposits of the World: Volume 2, Phosphate Rock Resources. IGCP 156: Phosphorites. Cambridge University Press.

Ohimain, E.I., 2014. Can Nigeria Generate 30\% of her Electricity from Coal by 2015? International Journal of Energy and Power Engineering, 3 (1), 28-37.

Pedley, A., Neubert, J. and van der Klauw, S., (this volume). Potash deposits in Africa.

Philander, C. and Rozendaal, A., 2015. Geology of the Cenozoic Namakwa Sands heavy mineral deposit, west coast of South Africa: A world-class resource of titanium and zircon. Economic Geology, 110, 1577-1623.

Porter, T.M., 2005. Ouenza, Bou Khrada, Algeria, www.portergeo. com.au, viewed February 2016.

RioTinto, 2014.Annual Report 2014. Production, Reserves and Operations. Accessed February 2016 on http://www.riotinto.com/ ar2014/pdfs/production-reserves-and-operations.pdf.

RioTinto, Guinea projects and operations, Simandou Project, 2015. About Simandou. Accessed February 2016 on http://www.riotinto. com/guinea/about-simandou-10974.aspx.

Robb, L.J., Cailteux J. and Sutton, S.J., Eds., 2005. Recent Advances on the Geology of the Central African Copperbelt. Journal of African Earth Sciences, 42(1-5), 1-210.

Robertson, M. and Peters, L., (this volume). West African Goldfields.

Robertson, M., 2013. Kitumba- a new kind of copper deposit in a Zambian context. S.A. Inst. Min. Metall. Base Metals Conference 2013. Accessed February 2016 onwww.basemetals.org/ WhiteRiver2013/001-Robertson.pdf.

Schmandt, D., Broughton, D., Hitzman, M.W., Plink-Bjorklund, P., Edwards, D. and Humphrey, J., 2013. The Kamoa copper deposit, Democratic Republic of Congo: Stratigraphy, diagenetic and hydrothermal alteration, and mineralization. Economic Geology, $108,1301-1324$.

Schreiber Jr, J.F. and Matlock, W.G.,1978. Phosphate Rock Industry in North and West Africa. The University of Arizona, Tucson, Arizona. 27p.

Schuh, W., Leveille, R.A., Fay, I. and North, R., 2012. Geology of the Tenke-Fungurume sediment-hosted strata-bound coppercobalt district, Democratic Republic of Congo. Soc. Econ. Geol., Spec. Publ. 16, 269-301.

Selley, D., Broughton, D., Scott, R.J., Hitzman, M., Bull, S.W.,Large, R.R., McGoldrick, P.J., Croaker, M. and Pollington, N., 2005. A new look at the geology of the Zambian Copperbelt. Economic Geology, 100th Anniversary Volume, 965-1000.

Selley, R.C. and van der Spuy, D., (this volume). The oil and gas basins of Africa. 
Sheppard, S.M.F., Charef, A. and Bouhel, S., 1996. Diapirs and Zn$\mathrm{Pb}$ Mineralization: A general mode based onTunisian (N. Africa and Gold Coast (U.S.A) Deposits. SEG Special Publication No. 4, pp. 230-243.

Smith, A.J.B. and Beukes, N.J., (this volume). Paleoproterozoic banded iron formation-hosted high-grade hematite iron ore deposits of the Transvaal Supergroup, South Africa.

Smith, A.J.B., Henry, G. and Frost-Killian, S., (this volume). A review of the Birimian Supergroup- and Tarkwaian Group-hosted gold deposits of Ghana.

Société Nationale Industrielle et Minière, 2013. Mine. Accessed February 2016 on http://www.snim.com/e/index.php/operations/ mines.html.

Soudry,D., Glenn,C.R., Nathan,Y., Segal,I. and von derHaar,D., 2006. Evolution of Tethyan phosphogenesis along the northern edges of the Arabian-African shield during the Cretaceous-Eocene as deduced from temporal variations of $\mathrm{Ca}$ and $\mathrm{Nd}$ isotopes and rates of $\mathrm{P}$ accumulation. Earth-Science Reviews, 78, 27-57.

Steven, N.M. and Badenhorst, F.,2002. Mesothermal gold deposits of the Damara Orogen. Excursion guidebook, 11th Quadrennial IAGOD Symposium and Geocongress, Windhoek, 225 pp.

Sundance Resources, 2015. Resources and Reserves - Ore Reserves. Accessed February 2016 on https://www.sundanceresources. com.au/irm/content/resources-reserves.aspx?RID=236.

Taib, M., 2009. The Mineral Industry of Algeria. U.S. Geological Survey Minerals Yearbook, 2009. Page 2.3.

Taylor, C.D., Causey, J.D., Denning, P.D., Hammarstrom, J.M., Hayes, T.S., Horton, J.D., Kirschnaum, M.J., Parks, H.L., Wilson, A.B., Wintzer, N.E. and Zientek, M.L., 2013. Descriptive models, gradetonnage relations, and databases for the assessment of sedimenthosted copper deposits- With emphasis on deposits in the Central African Copperbelt, Democratic Republic of Congo and Zambia.

USGS Scientific Investigations Report 2010-5090-J, 154 pp.

Tucker, R., Viljoen, R.P. and Viljoen, M.J., (this volume).A Review of the Witwatersrand Basin -The World's Greatest Goldfield.

Tyler, R.M. and Minnitt, R.C.A., 2004. A review of the sub-Saharan heavy minerals sands deposits: implication for new projects in southern Africa. J. Southern Afr. Inst. Min. Metall., March, 8999.

US Energy Information Administration - International Energy Statistics, 2013. Accessed January 2016 onhttps://www.eia.gov/ cfapps/ipdbproject/iedindex $3 . \mathrm{cfm}$ ?tid=1\&pid=7\&aid=1\& cid=r6,\&syid=2011 \&eyid=2012\&unit=TST.

USGS report, 2015. Accessed January 2016 onhttp://minerals.usgs. gov/minerals/pubs/commodity/.

Van Kauwenbergh S.J., 2002. Cadmium content of phosphate rocks and fertilizers, International Fertilizer Industry Association (IFA) Technical Conference, Chennai, India, September 2002.

Van Straaten, P., 2002. Rocks for Crops: Agrominerals of sub-Saharan Africa. ICRAF, Nairobi, Kenya, 338pp.

Viljoen, M., (this volume). The Bushveld Complex. Host to the World's Largest Platinum, Chromium and Vanadium Resources.

Warren, J.K., 2005. Evaporites: Sediments, Resources and Hydrocarbons. Springer. Chapter 11.

Wulff, K., Dziggel, A., Kolb, J., Venneman, T., Boettcher, M.E. and Meyer, F.M., 2010. Origin of mineralizing fluids of the Navachab sediment-hosted gold mine, Namibia: Constraints from stable (C, O, H, S) isotopes. Economic Geology, 105, 285-302.

Yao, Y. and Master, S., 2001. Hofrat en Nahas $\mathrm{Cu}-\mathrm{Au}-\mathrm{U}$ deposit, Sudan: Fluid inclusion evidence for a magmatic origin. In: Piestrzynski, A. et al. (Eds.), Mineral Deposits at the Beginning of the 21st Century. Swets \& Zeitlinger Publishers, A. A. Balkema, Lisse, The Netherlands, 839-842.

Zientek, M.L., Bliss, J.D., Broughton, D.W., Christie, M., Denning,
P.D., Hayes, T.S., Hitzman, M.W., Horton, J.D., Frost-Killian, S., Jack, D.J., Master, S., Parks, H.L., Taylor, C.D., Wilson, A.B., Wintzer, N.E. and Woodhead, J.,2014. Sediment-Hosted Stratabound Copper Assessment of the Neoproterozoic Roan Group, Central African Copperbelt, Katanga Basin, Democratic Republic of the Congo and Zambia. USGS, Global Mineral Resource Assessment, Sci. Investig. Rep. 2010-590-T, 162 pp.

Zwaan, J.C., Seifert, A.V., Vrána, S., Laurs, B.M., Anckar, B., Simmons, W.B., Falster, A.U., Lustenhouwer, W.J., Muhlmeister, S., Koivula, J.I. and Garcia-Guilerminet, H.,2005. Emeralds from the Kafubu area, Zambia. Gems \& Gemology, 41(2), 1-34.

\section{References used in the compilation of Figures 1a, $1 \mathrm{~b}$ and 2.}

Abdelsalam, M.G., Abdel-Rahman, E.-S.M., El-Faki, E.-F.M., AlHur, B., El-Bashier, F.R.M., Stern, R..J. and Thurmond, A.K., 2003. Neoproterozoic deformation in the northeastern part of the Saharan Metacraton, northern Sudan. Precambrian Research 123, pp. 203-221.

Council for Geoscience (South Africa). 2002. 1:5000 000 International Digital Metallogenic Map of Africa. Pretoria, South Africa: Council for Geoscience and Commission for the Geological Map of the World.

de Waele, B., Johnson, S.P. and Pisarevsky, S.A., 2008. Palaeoproterozoic to Neoproterozoic growth and evolution of the eastern Congo Craton: Its role in the Rodinia puzzle. Precambrian Research 160, pp 127-141.

Delpomdor, F. and Préat, A., 2015. Overview of the Neoproterozoic Sedimentary Series Exposed Along Margins of the Congo Basin. In de Wit, M.J., Guillocheau, F. and de Wit, M.C.J., (eds) Geology and Resource Potential of the Congo Basin, Regional Geology Reviews, Springer-Verlag Berlin Heidelberg. pp. 41-58.

Eglington, B.M. and Armstrong, R.A., 2004. The Kaapvaal Craton and adjacent orogens, southern Africa: a geochronological database and overview of the geological development of the craton, South African Journal of Geology, 107, pp. 13-32.

Hartnady, C., Joubert, P. and Stowe, C., 1985. Proterozoic Crustal Evolution in Southwestern Africa. Episodes 8, 4, pp. 236-244.

Jessell, M.W., Santoul, J., Baratoux, L., Youbi, N., Ernst, R.E., Metelka, V., Miller, J. and Perrouty, S., 2015. An updated map of West African mafic dykes. Journal of African Earth Sciences 112, Part B, pp. 440-450.

Johnson, P.R., Andresen, A., Collins, A.S., Fowler, A.R., Fritz, H., Ghebreab, W., Kusky, T. and Stern, R.J., 2011. Late CryogenianEdiacaran history of the Arabian-Nubian Shield: A review of depositional, plutonic, structural, and tectonic events in the closing stages of the northern East African Orogen, Journal of African Earth Sciences 61, pp. 167-232.

Kadima, E., Delvaux, D., Sebagenzi, S.N., Tack, L. and Kabeya, S.M., 2011. Structure and Geological History of the Congo Basin: an integrated interpretation of gravity, magnetic and reflection seismic data. Basin Research 23, pp. 499-527.

Karmakar, S. and Schenk, V., 2015. Neoproterozoic metamorphic events along the eastern margin of the East Sahara Ghost Craton at Sabaloka and Bayuda, Sudan: Petrology and texturally controlled in-situ monazite dating. Precambrian Research 269, pp. 217-241.

Lehmann, J., Master, S., Rankin, W., Milani, L., Kinnaird, J.A., Naydenov, K.V., Saalmann, K. and Kumar, M., 2015. Regional aeromagnetic and stratigraphic correlations of the Kalahari Copperbelt in Namibia and Botswana. Ore Geology Reviews 71, pp. 169-190.

Macey, P.H., Thomas, R.J., Grantham, , G.H., Ingram, B.A., Jacobs, J., Armstrong, R.A., Roberts, M.P., Bingen, B., Hollick, L., de Kock, G.S., Viola, G., Bauer, W., Gonzales, E., Bjerkgård, 
T.,Henderson, I.H.C., Sandstad, J.S., Cronwright, M.S., Harley, S., Solli, A., Nordgulen, Ø., Motuza, G., Daudi, E. and Manhiça, V., 2010. Mesoproterozoic geology of the Nampula Block, northern Mozambique: Tracing fragments of Mesoproterozoic crust in the heart of Gondwana, Precambrian Research 182, pp. 124-148.

Meinhold, G., Morton, A.C., Fanning, C.M., Frei, D., Howard, J.P., Phillips, R.J., Strogen, D. and Whitham, A.G., 2011. Evidence from detrital zircons for recycling of Mesoproterozoic and Neoproterozoic crust recorded in Paleozoic and Mesozoic sandstones of southern Libya. Earth and Planetary Science Letters 312, pp. 164-175.

Oosterhuis, W.R., 2015. Map - Mines, Mineral Deposits and Occurrences of Africa. Mining Review Africa and Council for

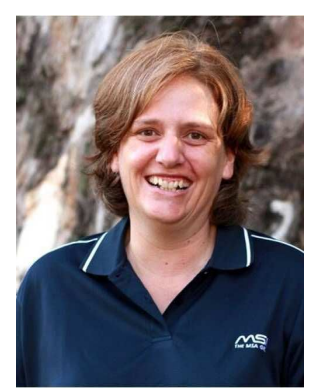

Susan Frost-Killian is a senior research geologist with The MSA Group (Pty) Ltd in Johannesburg, South Africa. She has almost twenty years professional experience covering: commodity, geological, and country research; metallogenic and prospectivity mapping; GIS; mineral assessments; technical editing and providing assistance with the compilation and submission of Competent Persons Mineral Resource Estimates, Scoping and Pre-Feasibility technical reports and due diligence reviews. Her experience covers regional and country specific projects in Africa, collaborative projects with African geological surveys, India, the United States, and some countries within the European Union, and country reports (minerals, geology, etc.) for various countries (global).

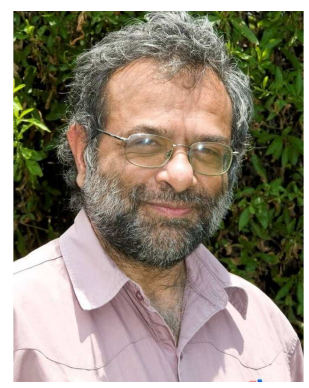

Sharad Master is a senior researcher and lecturer in the School of Geosciences, University of the Witwatersrand, where he obtained his degrees. In 1997/8 he was awarded a Visiting Fellowship at Harvard University. His eclectic research interests (with more than 40 peer-reviewed publications), include the regional geology, metallogeny and geochronology of Africa, and History of Geosciences. He has 15 years experience in industry, and has travelled and lectured extensively. As a voting member of the South African National Committee for IUGS/IGCP, he has attended five IGCs. A member of several geological societies, he has acted as peer reviewer for many journals.
Geoscience. January 2015.

Robb, L., 2014. Metallogenic models and the search for gold deposits. Presentation - ECOLE THEMATIQUE CNRS RESSOURCES MINERALES : LA VISION DU GEOLOGUE, Université Rennes 1, 8 au 11 Septembre 2014. Accessed February 2016 on https:// etressources.univ-rennes1.fr/.

Robertson, M. and Peters, L., (this volume). West African Goldfields. Vorster, C.J., 2000. Map of the Gold deposits of the Witwatersrand. Council for Geoscience. Accessed February 2016 on http:// www.geoscience.org.za/index.php/component/content/ article id=386: downloadable-maps-documents-and-files .

Wilson, M.G.C. and Annhaeusser, C.R. (Eds), 1998. The Mineral Resources of South Africa, $6^{\text {th }}$ Edition, Handbook 16. Council for Geoscience, Pretoria. 740 pp.

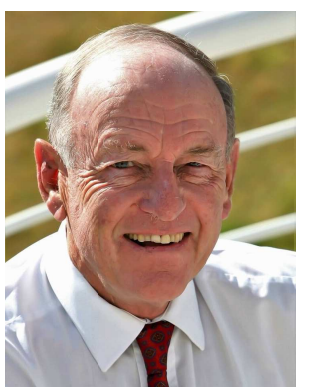

Richard Viljoen is Co-President of the $35^{\text {th }}$ $I G C$. Subsequent to extensive research studies in Archaean terrains, he spent most of his career in the mining industry. He was an Honorary Professor at the University of the Witwatersrand and is now a consultant for VMI / Bushveld Minerals. He is a fellow of five international and national Geoscience Societies and is the recipient of a number of awards including the Draper medal of the Geological Society of South Africa and the Lindgren award of the Society of Economic Geologists.

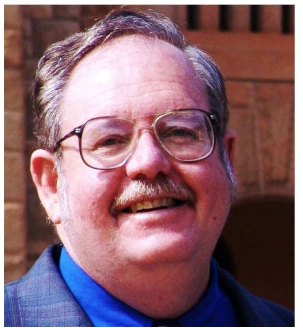

Mike Wilson has worked as an exploration geologist for more than 40 years, in both South Africa and Zimbabwe. He has worked on a wide range of minerals, from Archaean-hosted gold, nickel and emerald mineralisation, through Proterozoic sedimentary-hosted copper and other deposits. During a 14 year spell at the South African Council for Geoscience (previously Geological Survey), Mike was the principal contributor to and compiler and editor-in-chief of the benchmark publication The Mineral Resources of South Africa, as well as a book on The Occurrence of Diamonds in South Africa. He edited portions of World Bank sponsored publications on mineralisation in Mozambique and Madagascar, before being asked to edit this special volume on 'The Great Mineral Fields Africa'. Mike is a Fellow and former Vice President of the GSSA and serves on its Research, Education and Investment Committee. 